\title{
Über den Einfluß gewisser physikalisch-chemischer Faktoren auf Präzipitation und Agglutination. ${ }^{1}$
}

Von

\author{
Dr. St. Serkowski, \\ Leiter des Bakteriologischen Laboratorlums in Warschau.
}

Bei den über die Reaktion von Widal-Gruber und über die anf den Einfluß von Serum immunisierter Tiere zurückzuführende Bakterienagglutination von mir ausgeführten Versuchen habe ich zahlreiche Befunde wahrgenommen, welche von den üblichen Schlußfolgerungen bedeutend abweichend gewesen sind; ich beschloß daher, diese Befunde in einer Reihe systematischer Forschungen zu prüfen, deren Ausführung die Jahre 1914 und 1915 in Anspruch genommen hat. Der damit beabsichtigte Zweck war der folgende:

1. Das quantitative Verhältnis und den gegenseitigen Zusammenhang der drei an der Reaktion mitwirkenden Faktoren zu ermitteln;

2. zu untersuchen, inwiefern sich Präzipitine an spezifischen Sedimenten beteiligen, $d . h_{\text {, }}$ ob die Sedimente, außer Bakterienagglutinaten, aụch noch Globulinpräzipitate enthalten;

3. zu ermitteln, ob gewisse Reaktionen (wie z. B. die von Kraus bei Bakterienfiltraten angewendete Uhlenhuthsche Probe) ebenfalls für Bakteriensuspensionen anwendbar sind.

4. zu untersuchen, ob Präzipitate nicht durch ausschließlich katalytische Wirkung spezifischer Bakterien zu erzeugen wären, oder aber, ob die Mitwirkung von Bakteriensuspensionen, bzw. von deren Filtraten absolut erforderlich sei;

5. zu bestimmen, ob der beobachtete Anstieg des präzipitativ-agglutinativen Titers sich etwa nicht in Abhängigkeit stellen ließe: a) von der absoluten Quantität des Präzipitinogéns und Präzipitins; b) von Änderungen des Sättigungsgrades der NaCl-Salze von 0.85 bis 8.5 Prozent; c) von Substitution des $\mathrm{NaCl}$ durch $\left(\mathrm{NH}_{4}\right)_{2} . \mathrm{SO}_{4}$; vom Zusatz von

1 Vorgetragen am 15. Oktober 1915 in der Sitzung der. Warschauer Gesell. schaft der Wissenschaften. 
$\mathrm{CH}_{3} . \mathrm{COOH}$; e) vom Komplementzusatz; f) von Erwärmung der Bakteriensuspensionen $\mathfrak{u}$. dgl., und

6. zu ermitteln, ob überhaupt eine solche Änderung der Untersuchungsmethode zulässig wäre, welche das Erlangen eines beträchtlich höheren Titers ermöglichen und somit bei geringem Präzipitin- bzw. Agglutiningehalte positive Resultate gewähren würde (im Serum der Typhuskranken während des Initialstadiums, bei Tuberkulose, in Krankensekreten, in der Frauenmilch usw.).

Ich sehe davon ab, an dieser Stelle zu beschreiben die Ausfïhrungsweise von makroskopischer Agglutination in Kapillaren, in kleinen, engen, auf $1 \mathrm{cem}$ berechneten Röhrchen, in größeren Probiergläsern, auf Platten $u$. dgl. Sämtliche dieser Versuchsmethoden gehen von dem Standpunkte aus, daß die Resultate einer makroskopischen Probe auf den Verdünnungsgrad des Serums, sowie auf vorschriftsmäßige Darstellung der Bakteriensuspension zurückzuführen sind, ohne Rücksicht auf den Behälterumfang bzw. das Volumen der gemischten Flüssigkeiten (d. h. des verdünnten Serums und der Suspension).

Laut der üblichen Meinung kann ein gleicher Titer bei $0 \cdot 5,1 \cdot 0$, bei 5 oder 10 cem Gemisch erlangt werden; es handelt sich nur um den genauen Verdünnungsgrad des Serums.

Ob dieser Grundsatz den Tatsachen entspricht, tritt durch folgende' Versuche zutage: nach vorangehender Titerbestimmung (pro $1 \mathrm{ccm}$ ) wurden diverse Sera mit einem Volumen Suspension vermengt, welches deren Verhältnis ungeändert gelassen; das Gemisch wurde auf diese Weise dargestellt, daß die Menge der beiden Substanzen, mit Aufrechterhaltung des im ersten Probierglas vorhandenen Verdünnungsgrades, in jedem folgenden Probierglas vergrößert wurde, z. B. $1.1 \mathrm{~cm}$ Bakteriensuspension +1 Tropfen Präzipitin (Verdünnung 1 zu 100); 2. $2 \mathrm{ccm}$ Suspension +2 Tropfen Präzipitin; im 3. Glas $-3 \mathrm{ccm}+3$ Tropfen usw.

Befunde ${ }^{1}$ : Die Resultate der Präzipitation sind nicht allein von der Verdünnung des spezifischen Serums, sondern auch von der absoluten Menge der verbrauchten Substanzen abhängig. Beträgt bei Berechnung pro $1 \mathrm{ccm}$ der Titer des Gesamtgemisches 1:200, so können bei fünffachen Mengen, sogar bei 1:2000, Sedimente erhalten werden; bei hochagglutinierendem Serum beträgt der

1 An den vorgeführten, wie auch an weiteren Versuchen haben sich meine Mitarbeiter: A. Sachnowski, J. Przyborowski, K. Sterling, L. Szereszewski und T. Raniecki beteiligt, wofür ich ihnen hier meinen höflichsten Dank ausdrủcke. 
Anstieg des Titers 1:2500 bis 1:20000; bei allmählich anwachsenden Mengen steigt der Titer der Sera unbegrenzt an. Daraus folgt ein weiterer Schlußsatz: Sollte das Serum eines Typhuskranken im Initialstadium, bei üblicher Verdünnung $(1: 25-50-100)$ und bei Anwendung von $1 \mathrm{ccm}$ Gemisch nicht agglutinieren, so ist die Agglutination in stärkeren Dosen zu wiederholen (5 bis $10 \mathrm{fach}$ ), bei ungeänderter Verdünnung des Serums. Das gleiche bezieht sich auf andere Infektionsprozesse, wie Ruhr, Tuberkulose u. dgl.

Das Resultat der Sedimentation ist auf die absolute Menge der Bestandteile zurückzuführen, eine Menge, die nur insofern von der Verdünnung der Präzipitine bzw. der Agglutinine abhängt, als bei einer ungeheuren Verdünnung der letzteren die absolute Menge der Bestandteile anstatt 3 oder 5 mal, 8 bis 10 mal zu vergrößern ist; diese Abhängigkeit tritt durch die in Tabelle II zusammengestellten Versuche zutage.

Was die Erhöhung des Agglutinationstiters unter dem Einfluß der im Serum selbst stattfindenden Änderungen betrifft, so ist ein soleher, auf verschiedene Ursachen zurückzuführender. Anstieg von den Forschern hier und da beobachtet worder. So haben z. B. R. Scheller', Glässner ${ }^{2}$ und F. Eisenberg ${ }^{3}$ bei länger stehen gelassenen Sera einen Anstieg des Titers im Vergleich zu den frischen Sera wahrgenommen.

Indem ich in der Theorie der Kolloide nach einer Erläuterung der vorgeführten Phänomene suche (Tabb. I und II), welche mehr auf Bedeutung des Volumens beider Bestandteile, als auf Verdünnung des spezifischen Serums beruhen, bin ich nicht imstande, daselbst eine genaue Analogie zu finden. Mehrmals wurde ein Zusammenhang zwischen dem osmotischon Drucke und der Teilchenzahl des bestimmten Volumens beobachtet.4

Es ist wohl möglich, daß auch in dieser Erscheinung der Teilchenzahl eine gewisse Bedeutung zufällt. Die Kolloidlösungen pflegen sich öfters zu ändern, parallel mit den in den Teilchen selbst vor sich gehenden Änderungen: Amikronen werden zu Submikronen, und zuletzt erfolgt die Koagulation mit simultaner Erniedrigung des osmotischen Druckes. Da der Einfluß von Elektrolyten auf den osmotischen Druck von Eiweiß festgestellt ist, so bewirkt die Salzlösung auch in diesem Falle, auf größere Eiweißmengen einwirkend, eine Erniedrigung dessen osmotisehen Druckes: die Mikronen selbst erleiden Änderungen, worauf Koagulation erfolgt.

1 Centralbl. f. Bakteriol. 1904. Bd. XXXVI. S. 427,694 u. 1905. Bd. XXXVIII. S. 100 .

2 Zeitschr. f. exp. Path. u. Ther. 1905. Bd. I. S. 640.

${ }^{3}$ Centralbl. $f$. Bakteriol. 1906. Bd. XLI. S. 96 u. folgende.

4 R. Zsigmondy, Kolloidchemie. 1912. S. 42. 
Trotzdem ist die vorgeführte Auseinandersetzung nicht imstande, uns weder den Einfluß und die Beteiligung des spezifischen Serums, noch die Bedeutung der vergrößerten Präzipitinogenmengen zu erläutern.

Tabelle I.

\begin{tabular}{|c|c|c|c|c|c|c|c|c|c|c|c|}
\hline Titer pro $1 \mathrm{ccm}$ & 50 & 100 & 200 & 250 & 500 & 1000 & 2000 & 4000 & 8000 & 10000 & Kontr. \\
\hline $\begin{array}{l}\text { Aochagglutinierendes } \\
\text { Typhusserum . . . }\end{array}$ & + & $1++$ & ++ & ++ & ++ & $1+1$ & + & - & - & - & - \\
\hline $\begin{array}{l}\text { Serum eines Typhus- } \\
\text { kranken (9 Tage). }\end{array}$ & $\approx h$ & ++ & $1+t$ & $1+t$ & - & - & - & - & - & - & - \\
\hline $\begin{array}{l}\text { Hochagglutinierendes } \\
\text { Choleraserum . . }\end{array}$ & ++ & $1++1$ & $1++$ & $1++$ & $t+$ & ++1 & ++1 & ++1 & - & - & - \\
\hline
\end{tabular}

Tabelle I (Fortsetzung).

Agglutination oberhalb des ,Titers".

Serum- und Suspensionsmengen werden allmählich vergrößert, doch bleibt dabei das Verhältnis des ersten zum zweiten, sowie die Verdünnung in jedem der 6 Probiergläser ungeändert.

\begin{tabular}{|c|c|c|c|c|c|c|c|c|}
\hline & & & sp. & v. $1-$ & $-6 \mathrm{ce}$ & & & Bemerkungen \\
\hline & 1 & 2 & 3 & 4 & 5 & 6 & & \\
\hline $\begin{array}{l}\text { Hochaggl. Typhusser., } \\
\text { verd. } 1: 4000+\text { Typhus- } \\
\text { suspension . }\end{array}$ & - & - & \pm & + & ++ & ++ & - & $\begin{array}{l}\text { Im 5. u. 6. Probierglas-Prä- } \\
\text { zipitat ebenso gro (trotz } \\
\text { der Verdünnung 1:4000) } \\
\text { wie oben bei Verdünnung } \\
1: 100-1000 \text {. }\end{array}$ \\
\hline $\begin{array}{l}\text { Hochaggl. Typhusser., } \\
\text { verd } 1: 8000+\text { Typhus- } \\
\text { suspension }\end{array}$ & - & - & \pm & \pm & ++ & ++ & - & $\begin{array}{l}\text { Präzipitat im 5. u. 6. Pro- } \\
\text { bierglas bei } 1: 8000=\text { Prä- } \\
\text { zipitat bei } 1: 100-1000 \text {. }\end{array}$ \\
\hline $\begin{array}{l}\text { Serum eines Typhus- } \\
\text { kranken (10Tage), verd. } \\
1: 1000+\text { Typhussus- } \\
\text { pension } . .\end{array}$ & - & - & \pm & ++ & ++ & ++ & - & $\begin{array}{l}\text { Präzipitat im } 4 ., 5 \text {. und } 6 \\
\text { Probierglas bei Serumver- } \\
\text { dünnung } 1: 1000=\text { dem } \\
\text { Präzipitat bei Verdünnung } \\
1: 100 \rightarrow 200 \text {. }\end{array}$ \\
\hline $\begin{array}{c}\text { Serum des gleichen Kr., } \\
\text { verd. } 1: 2000+\text { Typhus- } \\
\text { suspension }\end{array}$ & - & - & \pm & ++ & ++ & $+\div$ & - & $\begin{array}{l}\text { Wie oben, trotz der Serum- } \\
\text { verdünnung } 1: 2000 \text {. }\end{array}$ \\
\hline $\begin{array}{l}\text { Hochaggl. Choleraser., } \\
\text { verd. 1:10000 + Suspen- } \\
\text { sion v. Vibrio Cholerae }\end{array}$ & - & \pm & $t$ & $+t$ & $1+$ & +++ & - & $\begin{array}{l}\text { Präzipitat in 4., 5. u. } 6 . \\
\text { Probierglas bei Serumver- } \\
\text { dünnung } 1: 10000=\text { dem } \\
\text { Präzipitat } 1: 50-4000 .\end{array}$ \\
\hline $\begin{array}{l}\text { Hochaggl. Choleraser., } \\
\text { verd. 1:20000+ Suspen- } \\
\text { sion v. Vibrio Cholerae }\end{array}$ & - & - & \pm & ++ & ++ & ++ & - & $\begin{array}{l}\text { Wie oben, trotz der Serum. } \\
\text { verdünnung } 1: 20000 \text {. }\end{array}$ \\
\hline $\begin{array}{l}\text { Hochaggl. Choleraser., } \\
\text { verd. 1: 20000 + Ty- } \\
\text { phussuspension : }\end{array}$ & - & - & - & - & - & - & 一 & $\begin{array}{l}\text { Zweite Kontrolle, suspen- } \\
\text { sionsloses Serum ebenfalls } \\
\text { negativ. }\end{array}$ \\
\hline
\end{tabular}


Diese Versuche sind 4 mal wiederholt worden mit gleichen positiven Resultaten in den Probiergläsern 4 bis 6; nur im 2. und 3. Probierglas sind geringe Differenzen beobachtet worden.

\section{Tabelle II.}

Serumtiter bleibt ohne Änderung. Die Menge der beiden Substanzen wächst gleichmäßig um den Inhalt des ersten Probierröhrchens, auf solche Art, daß wir in dem zweiten Probierröhrchen 2 mal Suspension der ersten, in drittem $=3 \times 1$ usw. haben.

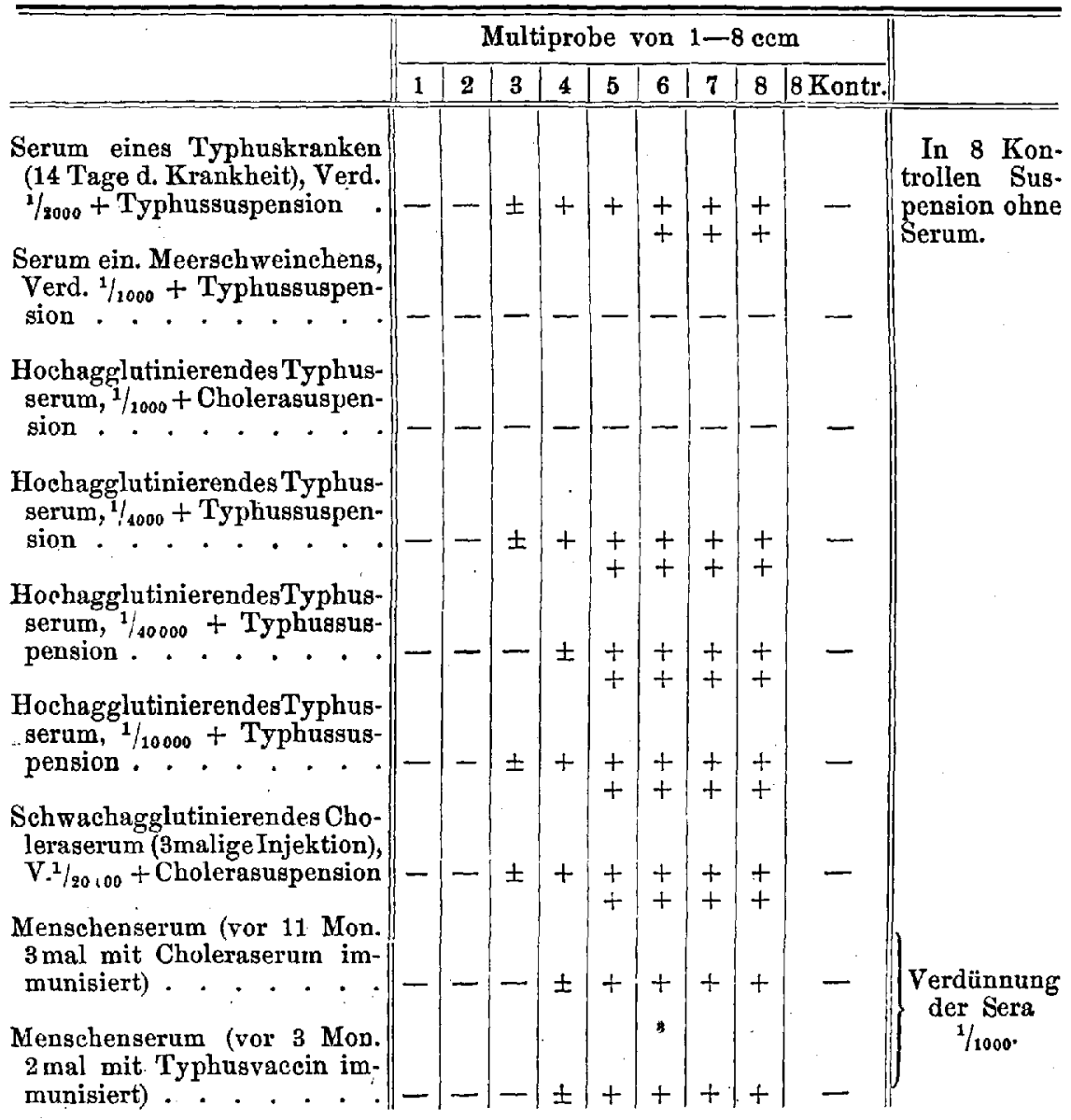

Prinzipiell ist bei Darstellung von spezifischen Niederschlägen das Phänomen der Agglutination von demjenigen der Präzipitation getrennt zu halten: die erste Bezeichnung umfaßt die Sedimentation von Bakterien- 
körpern, die zweite dagegen die Koagulation der in Extrakten und bakterienlosen Filtraten gelösten Verbindungen. Sowohl die erste, als auch die zweite Erscheinung erfordert eine parallele Mitwirkung von drei Faktoren, und zwar von Antigen (Agglutinogen bzw. Präzipitinogen), von Antikörper (Agglutinin bzw. Präzipitinin) und von physiologischer Kochsalzlösung.

Zahlreiche der bestehenden Arbeiten bezwecken entweder eine Identifikation oder Analogie dieser beiden Phänomene, oder aber dieselben beabsichtigen eine Ermittelung von prinzipiellen Unterschieden zwischen den beiden Erscheinungen. Gestützt auf Beobachtungen aus meiner Praxis, möchte ich hier die Meinung aussagen, daß beide Erscheinungen gleichzeitig in einen und denselben Probiergläsern erfolgen können, und zwar sowohl unter dem Einfluß von Serum kranker, wie immunisierter Tiere in Verbindung mit einer entsprechenden Bakteriensuspension: die Agglutination wird fast ausnahmslos von Präzipitation begleitet. Bei niedrigeren Verdünnungen pflegt die letztere die erstere derart zu übersteigen, daß wir von positiver Agglutination in denjenigen Fällen sprechen, in welchen Präzipitation beobachtet werden müßte. Nicht allein bei gewöhnlicher makroskopischer Untersuchung, sondern auch durch Abwägen konnte ich feststellen, daß das Präzipitat 10 bis 20 mal die verwendete Menge der Bakterienkörper überstieg. Auch mikroskopisch hatte ich öfters Gelegenheit, wahrzunehmen, daß in spezifischen Agglutinaten Bakterienkonglomerate eine versehwindende Minderheit bilden, wogegen der Niederschlag meist aus amorphen, bakterienlosen Massen und Flocken besteht: somit hat das Präzipitat Übergewicht über das Agglutinat.

Bei Versetzen der Bakteriensuspensionen mit entsprechendem spezifischen Serum, in einer Reihe von Probiergläsern bei allmählich abnehmenden Mengen, d. $h$. in stets anwachsender Verdünnung, beobachten wir beständig eine beträchtliche "Agglutination" $(+++)$ in den schwächeren Verdünnungen, und eine unvollständige $( \pm)$ in den stärkeren.

Meiner Ansicht nach könnte diese allgemein bekannte Tatsache damit erklärt werden, daß die sogenannte ausgesprochene Agglutination eine Verbindung von Agglutination und Präzipitation ist, und die unvollständigen Niederschläge ausschließlich Agglutinate enthalten; mit anderen Worten: der Agglutinationstiter des Serums ist stets höher, als der Präzipitationstiter. Wird sogar nach ausgeführter Reaktion kein teilweiser Niederschlag erhalten, was mitunter bei beträchtlichen Verdünnungsunterschieden vorzukommen pflegt $(200-100-500 \mathrm{u}$. dgl.), so erfolgt derselbe dennoch, sobald wir eine genauere Abstufung oder geringere 
Differenzen zwischen den aufeinanderfolgenden Verdünnungsgraden eingehalten haben.

Es ist mir öfters vorgekommen, eine unvollständige Widalsche Reaktion (oder die eigentliche Agglutination) bei Serumverdünnung 1 zu 250 zu erhalten; eine beträchtlichere dagegen bei 1 zu 200; dabei habe ich aber nur in der letzteren Verdünnung Präzipitat, selbstverständlich mit Agglutinat, feststellen könnem.

Um die chemischen Eigenschaften der erzeugten Niederschläge zu ermitteln, habe ich folgende Versuche ausgeführt: mit Hilfe einer Kapillarpipette beseitigte ich die Flüssigkeit oberhalb des Niederschlages und wusch denselben zweimal mit physiologischer Kochsalzlösung. Das ausgewaschene Sediment zeigte sich unlöslich in destilliertem Wasser, löste sich dagegen in schwachen Lösungen von Salz und Lauge auf. Nach Beseitigung der Salzlösung löste ich den Rüekstand in schwacher Natriumlauge auf (1 Prozent). Sodann habe ich die gewonnene Flüssigkeit, welche geringe Mengen von unlöslichen Flöckchen enthielt, durch ein chemisch reines Papierfilter zweimal passieren lassen und führte mit dem klaren Filtrat folgende Reaktionen aus:

1. Einem Teil dieses Filtrates wurde ein gleiches Volumen von gesättigter Ammoniumsulfatlösung beigemengt, wobei eine ausgesprochene, nach und nach niederfallende Trübung beobachtet wurde. Magnesiumsulfat erzeugt bei gesättigter Flüssigkeit ebenfalls Sedimente.

2. Der zweite Teil des Filtrates wurde mit einem Tropfen verdünnter Essigsäure versetzt; auch bei dieser Probe erfolgte. Trübung und nach einer gewissen Zeit ein geringes, flockenartiges Sediment.

3. Der dritte Teil des Filtrates wurde mit 10 prozentiger Phosphorwolframsäure vermischt; im Berührungspunkte beider Flüssigkeiten bildete sich ein weißer Ring.

4. Der vierte Teil trübte sich nach Zusatz von Alkohol und bildete nach einiger Zeit einen Niederschlag.

Sämtliche der vorgeführten Proben, besonders aber die erstere, scheinen dafür zu sprechen, daß Sedimente aus Verbindungen bestehen, die der Globulingruppe gehören. Nur ein geringer Teil des Niederschlages, in Gestalt von unlöslichen Flöckchen, bestand aus Bakterien, zum Teil aus Globulin, da die unvollständige Löslichkeit in Lauge gleichfalls auf längeres Verbleiben der Sedimente in Kochsalzlösung zurückgeführt werden kann: nach längerem Verbleiben in Wasser- oder in Salzlösungen werden gewisse Globulinarten ebenfalls unlöslich.

Die weiteren von mir ausgeführten Versuche bezweckten zu ermitteln, ob die präzipitative Ringreaktion von Uhlenhuth, deren sich Kraus 
bei bakterienlosen Filtraten bediente, auch für Bakteriensuspensionen vermittelst Schichtung mit entsprechendem spezifischen Serum anwendbar. sei. Ich griff zu dieser Reaktion auch bei der von meinem Mitarbeiter Br. Kretkowski ${ }^{1}$ für latente Blutungen vorgeschlagenen Modifikation. Und zwar vermengte ich spezifisches, verdünntes und unverdünntes Serum in sehr schmalen Probiergläsern mit einer dichten Suspension von entsprechenden Bakterienarten - nicht in physiologischer Kochsalzlösung, sondern in doppelter Konzentration; mit Hilfe einer Pipette träufelte man ganz vorsichtig die Suspension den Wänden entlang ein, um zwei Schichten zu bilden. Bei konzentriertem Serum kam die Suspension oberhalb desselben, bei verdünntem dagegen -- unterhalb zu liegen.

Ich bemerkte, daß bei Anwendung von homologem Präzipitin und Präzipitinogen ein weißer Ring entsteht an der Berührungsstelle beider Flüssigkeiten, sofort nach geschehener Stratifikation, - z. B. Serum eines Typhuskranken nebst dichter Suspension von Typhusbazillen in 1.7 proz. Kochsalzlösung.

Der Ring pflegt sich gewöhnlich sofort und jedenfalls nicht später als in 20 bis 40 Minuten, bei Zimmertemperatur zu bilden. Diese Reaktion war zuweilen so auffallend, $\mathrm{da} ß$ in einer langen Reihe von Probiergläsern dasjenige sofort bestimmt werden konnte, in welchem die beiden in Berührung kommenden Substanzen gegenseitig spezifisch gewesen.

Dergleichen Versuche sind in Hunderten ausgeführt worden; ich sehe indes von deren eingehender Beschreibung ab, da sich diese Proben endguiltig als in der Praxis unausführbar zeigten. Und zwar pflegt es vorzukommen, $d a ß$ eine und dieselbe mit gleichen Reagenzien, in mehreren Probiergläsern ausgeführte Reaktion nicht ganz übereinstimmende Resultate gibt - in den einen positive, in anderen dagegen - negative. Bei den letzteren bilden sich Sedimente an Stelle der Ringe. Die Resultate werden beeinflußt durch die Dichte der Suspension, durch mehr oder minder sorgfältige Schichtung, sowie auch durch öftere Bildung von nichtspezifischen Niederschlägen, infolge von übermäßiger Sättigung des Serums und von der Suspensionsdichte.

Um Präzipitate zu erhalten, darf man anstatt Bakteriensuspensionen oder Filtraten auch ausgetrocknete Bakterienpräparate anwenden. Ich gelangte $\mathrm{zu}$ diesem Befunde, indem ich feinste Kapillarröhrchen in 1:1 bis 1:1000 fach verdünntes Serum von Typhuskranken eintauchte. Die Oberfläche der Kapillaren wurde mit einer dünnen Schicht von Typhussuspension iiberdeckt, darauf getrocknet und vor dem Eintauchen sorg-

1 St. Petersburger Medininische Wochenschrift. 1909. 
fältig ausgewaschen, um die Bakterienzellen mit dem Serum in Berührung zu bringen, ohne dabei Suspension zu bilden. Das in gewissen Probiergläsern, unter dem Einfluß der katalytisehen Bakterienwirkung, inneroder außerhalb der Kapillaren erzeugte meßbare Präzipitat beweist, daß sogar bei Fehlen von Suspension oder Filtrat ein spezifischer Niederschlag erhalten werden kann. Meßbare Sedimente werden bei Anwendung von größeren Serummengen erhalten (bis 3 bis $5 \mathrm{ccm}$ ), manchmal auch bei $1 \mathrm{ccm}$, doch wird dabei das Resultat durch die folgende, schwer zu verfuillende und nachzupriffende Bedingung erschwert, und zwar soll die Schicht der ausgetrockneten Bakterien ziemlich dicht der Oberfläche fest anliegend und durch Wasserstrom nicht fortzuspülen sein. Bezügliche Versuche sind recht oft vorgenommen worden, doch sehe ich von der Beschreibung derselben $a b$, mit Rücksicht auf oben angeführte Gründe, welche sowohl die vorgeführten, als auch die Ringprobe in deren peaktischer Anwendung unausführbar machten.

Seit der Entdeckung der Gruber-Widalschen Reaktion wurde von zahlreichen Forschern bereits beobachtet, daB eine positive Reaktion gewöhnlich nicht früher als am 7. bis 11. Krankheitstage erhalten werden kann. Zwar kommen seltene Fälle von positiver Reaktion bereits am 3 . bis 5 . Tage vor, doch sind diejenigen weit zahlreicher festgestellt worden, in denen die Widalsche Reaktion erst am 18., 22., 25., 32., ja sogar am 40. Krankheitstage erfolgt war. Somit schlägt die serodiagnostische Reaktion bereits im ersten Typhusstadium fehl, wo eine frühzeitige Diagnose von größtem Wert sein würde.

Auch bei Tuberkulose führt die Agglutination zu Enttäuschungen. Wie bekannt (Arloing und Courmont 1898), agglutiniert das Serum von Tuberkulösen entweder überhaupt nicht, oder es bildet Sedimente bei Verdünnungen etwas über die Norm - 1:5 bis 20; nach Jessen wäre 1:25 der niedrigste Titer. Infolgedessen konnten bei völlig gesunden Individuen bis 30 Prozent positive Resultate beobachtet werden (13 bis 25 Prozent bei Paltauf, 22 bis 25 Prozent nach Carrières); dagegen beträgt bei den mit Tuberkulose, ja sogar mit Miliartuberkulose befallenen Subjekten, die positive Serumreaktion 15 bis 88 Prozent der Fälle nach dem ersten, und 51 bis 58 Prozent nach dem zweiten dieser Forscher.

Demnach bestehen zahlreiche Befunde dafür, daß sowohl im ersten Typhusstadium, wie auch bei Tuberkulose, das Krankenserum einen zu kleinen Antikörpergehalt zeigt, im Vergleich zu demjenigen, welcher unbedingt nötig ist, um die serodiagnostischen Reaktionen - die Agglutination und die Präzipitation - an den. Tag treten zu lassen. Wir müssen unumgänglich eine Konzentration von Antikörpern, sowie auch ein 
Sensibilisieren der Reaktion selbst, bzw. einen Titeranstieg zu erlangen suchen.

Was nun die Konzentration von Antikörpern in antitoxischen Sera betrifft, so sind dafür recht zahlreiche Methoden vorgeschlagen worden ${ }^{1}$ : von den mehr bekannten erwähne ich der Methode von Gibson - vermittelst Fällung mit Ammoniumsulfat (3 fache Konzentration), derjenigen von Gibson-Banzhaf (5 fache Konzentration) nebst der neueren Methode von Brieger-Krause (Chlornatrium), von Brunner-Pinkus - mit Natriumsulfat $u$. dgl. Von diesen Befunden kann bei Präzipitinenkonzentration kein Gebrauch gemacht werden (wegen der kleinen Menge des Krankenserums).

In einem engen Zusammenhange mit dem Bereiche der von mir vorgenommenen und ausgeführten Versuche steht die bisher noch nicht endgültig gelöste Frage, mit welcher Globulinfraktion sich die spezifischen Präzipitine verbinden. Bezügliche Forscherbefunde sind völlig divergent, und es ist noch nicht genau bekannt, ob Präzipitin und Agglutinin durch Euglobulin oder durch Pseudoglobulin gebunden werden²: es ist nur festgestellt worden, daß keiner der Antikörper durch Albumin gebunden wird. Demzufolge war ich in der weiteren Ausführung meines Versuchsplanes außer Stande, die einzelnen Fraktionen zu berücksichtigen; ich suchte nur, wenn möglich, die Aufklärung dieser Frage auf empirischem Wege zu finden. Somit bediente ich mich bei Darstellung von Suspensionen abnehmender Verdünnungen von $\left(\mathrm{NH}_{4}\right)_{2} \mathrm{SO}_{4}$ von 76 bis 0.59 Prozent, oder zunehmender Konzentration von $\mathrm{NaCl}$ von 0.85 bis 8.5 Prozent, allein oder mit Zusatz von $\mathrm{CH}_{3}$. $\mathrm{COOH}$.

Ich gebe hier einen Teil der ausgeführten Proben an (s. Tabb. III, IV und V).

1 Über Konzentration von Antikörpern durch Einfrieren (Methode von Buj. wid) sowie durch Trennung des Globulins von Serum, siehe bei Samuely, im Handbuch von Abderhalden, Handbuch d. biochemischen Arbeitsmethoden. 1910. Bd.II. S. 360; bei Hoppe-Seyler, Handbuch d. phys, u. path. chem. Analyse. 1909. 8. Aufl. S. 406; zum Teil im Handbuch d. physiol. Chemie von Hammarsten, f. Biochemie von Oppenheimer und in den "Methoden d. Antikörperdarstellung" von M. Ficker (Kolle-Wassermann. Bd. II, S. 210ff.).

2 So sind z. B. Präzipitine mit Euglobulin vollständig (Pick, Bang) oder nur zum Teil gebunden (Franceschelli); die Typhusagglutinine binden sich meist mit Pseudoglobulin (Pribram), Schutzagglutinate und Antitoxine im Serum von Ziegen, Pferden und Kaninchen mit der Euglobulinfraktion (Gibson und Collins); Hämolysine in beiden Fraktionen (Fuhrmann), Antitoxine im Euund Pseudoglobulin. Näheres siehe bei Franceschelli. Arch. f. Hygiene. 1909. Bd. LXIX. S. 207; Pribram im Handbuch von Kraus.LLevaditi, Bd. II. S. 87 und Ficker im Handbuch von Kolle-Wassermann, Bd. II. S. 230. 
Einfluss gewisser PhysiK.-Chem. Faktoren auf Präzipitation Usw. 165

\section{Tabelle III a.}

Präzipitation und Agglutination einer Typhussuspension, welche in verschiedenen Konzentrationen von $\mathrm{NaCl}(0.85$ bis 8.5 . Prozent), untèr dem Einfluß von Typhusserum eines 9 mal mit Typhusvaccine immunisierten Kaninchens dargestellt wurde. Um Spontansedimente zu verhüten, wurden sämtliche Suspensionen vorher 2 Stunden im Brutofen gelassen. Mit jeder Kochsalzlösung wurden 9 Proben ausgeführt: Verdünnung des Serums 1:50 bis 1:20000. Jede Probe mit $1 \mathrm{ccm}$ Suspension. Kontrolle $k_{1}$ enthält serumlose Suspension, $k_{2}$-Suspension mit Serum in Verdünnung $1 \mathrm{zu} 2000$ (wie im Probierglas 6), mit Zusatz von 1 Tropfen 10 prozentiger Essigsäure.

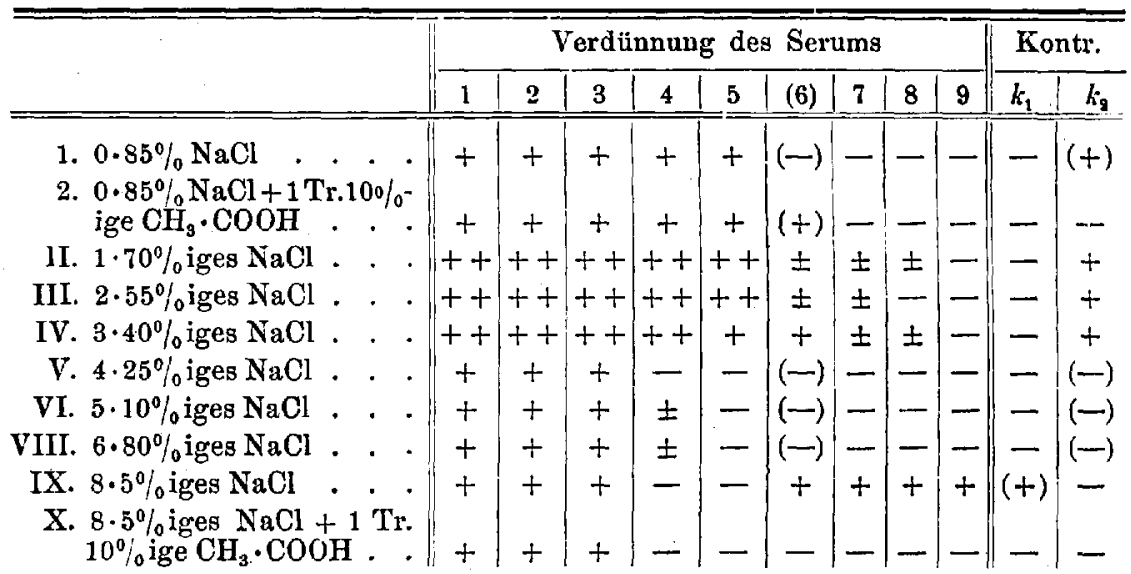

Die Resultate wurden dreimal nachgeprïft: nach 8, 16 und 24 Stunden. Nach 8 Stunden erfolgte die stärkste Präzipitation in den Probiergläsern mit Zusatz von $\mathrm{CH}_{3} \cdot \mathrm{COOH}$; nach 24 Stunden gleich wie nach 16 . Ein Titeranstieg mit Hilfe von Essigsäure wurde nur in schwächeren Konzentrationen von $\mathrm{NaCl}(0.85$ und 1.70 Prozent) beobachtet. Nichtspezifischer Niederschlag erfolgte nur bei $8 \cdot 5$ prozentigem säurelosen $\mathrm{NaCl}$. In säurelosen Agglutinationen zeigten 1.79 und 2.55 prozentige Konzentrationen von $\mathrm{NaCl}$ den höchsten Titer.

Das Vorhandensein von Essigsäure bewirkt stets einen Titeranstieg, insofern die Salzsättigung in der Suspension $2 \cdot 55$ Prozent nicht überschreitet; bei höherem Sättigungsgrade ist die Wirkung eine direkt entgegengesetzte: die Essigsäure setzt den Titer herab. t'brigens pflegen in den 8.5 Prozent sich nähernden Sättigungen spontane Sedimente in den serumlosen Kontrollen zu erfolgen. 
So hat z. B. das Serum eines Typhuskranken (14. Krankheitstag) in folgenden Verdünnungen mit spezifischer Suspension (pro $1 \mathrm{ccm}$ ) spezifische Niederschläge erzeugt:

Tabelle III b. .

Cholerakulturen Nr. 26 und 27.

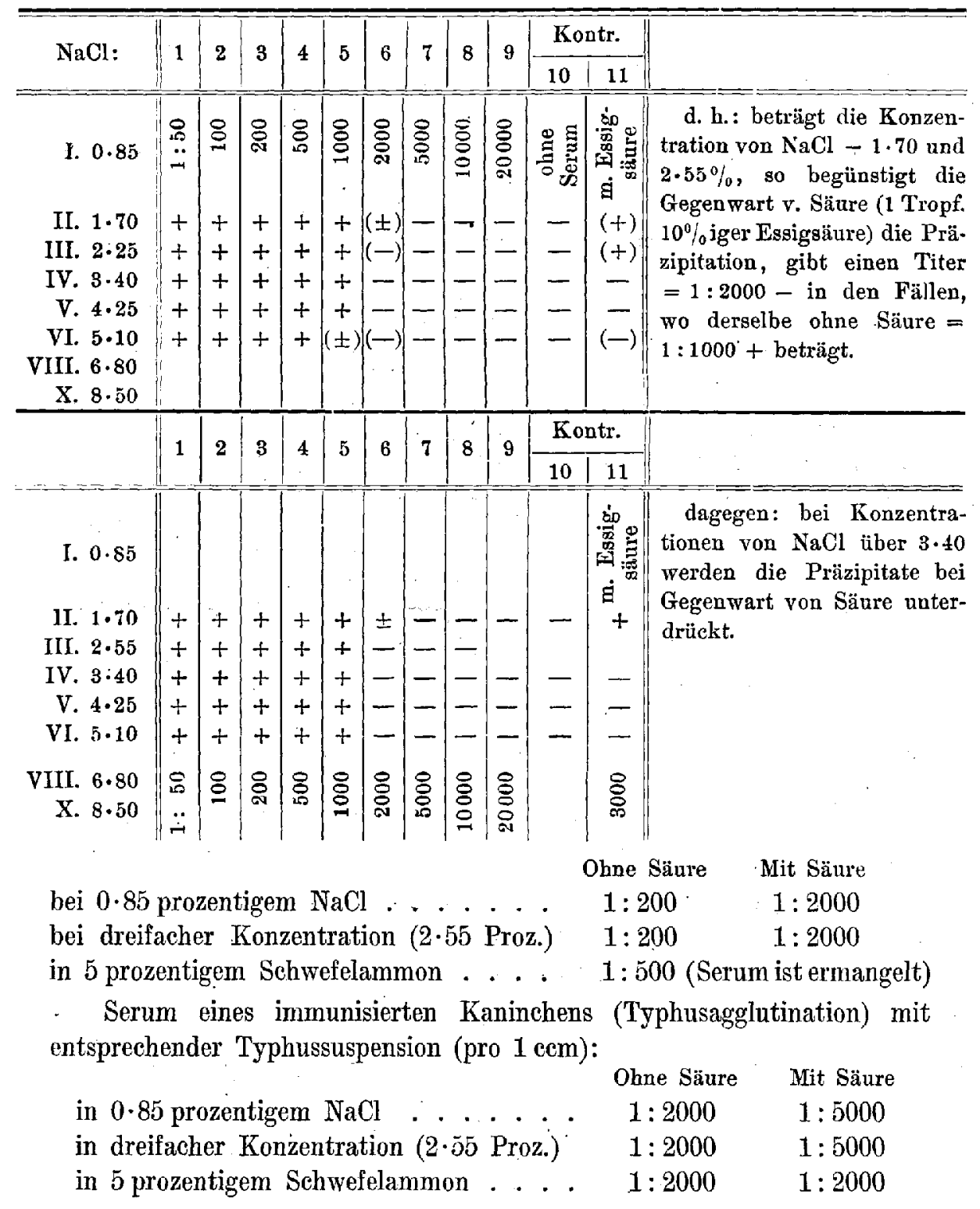


Tabelle IV.

Präzipitativ-agglutinativer Titer nach 15 Minuten, in 4 Stunden und in 24 Stunden. Serum eines fünfmal mit gemischter Choleravaccine immunisierten Kaninchens. Blut vermittelst einer Spritze aus dem Herzen gesammelt. Proben ausgefiihrt einige Stunden darauf, nach vorangehender Serumabsonderung; Suspension dargestellt mit der Cholerakultur Nr. 36, d. h. mit einer von den die Vaccine zusammensetzenden Kulturen. Allein + ist in Rechenschaft gezogen worden; \pm ist unberücksichtigt geblieben.

Titerberechnung pro $1 \mathrm{ccm}$.

\begin{tabular}{c||c|c|c} 
& nach 15 Min. & in 4 Std. & in 24 Std. \\
\hline I. $0 \cdot 85 \mathrm{NaCl}$ & $1: 50$ & $1: 50$ & $1: 100$ \\
II. 1.70 & $1: 100$ & $1: 100$ & $1: 200$ \\
III. $2 \cdot 55$ & $1: 200$ & $1: 200$ & $1: 200$ \\
IV. $3 \cdot 40$ & $1: 200$ & $1: 200$ & $1: 200$ \\
V. $4 \cdot 25$ & $1: 200$ & $1: 500$ & $1: 2000$ \\
VI. $5 \cdot 10$ & $1: 200$ & $1: 200$ & $1: 500$ \\
VII. $5 \cdot 95$ & $1: 200$ & $1: 200$ & $1: 1000$ \\
VIII. 6.80 & $1: 200$ & $1: 200$ & $1: 1000$ \\
IX. $7 \cdot 65$ & $1: 200$ & $1: 200$ & $1: 1000$ \\
X. 8.5 & $1: 200$ & $1: 200$ & $1: 5000$ \\
& &
\end{tabular}

Nr. IX zeigt ein größeres, Nr. X dagégen ein kleineres Spontansediment im Kontrollprobierglas (Suspension serumlos).

Der gleiche Versuch ist tags darauf wiederholt worden; der höchste Titer wurde von neuem mit der Kultur von Choleravaceine Nr. 36 in der V. Probe erhalten, d. h. bei einer 4.25 prozentigen Kochsalzlösung; in den Kontrollen hat nur die Probe X $(8 \cdot 5$ prozentiges $\mathrm{NaCl})$ nichtspezifischen Niederschlag gezeigt. Indem man die vorgeführten Proben mit einer sehr dünnen, kaum opalisierenden Suspension modifizierte, erhielt man im Probierglas V sogar einen höheren Titer 1 : 2500. Die übrigen Cholerakulturen zeigten nicht ganz übereinstimmende Resultate (Tabelle V).

Serum eines immunisierten Kaninchens (Paratyphusagglutination B) mit entsprechender Paratyphussuspension (pro $1 \mathrm{ccm}$ ):

$\begin{array}{lcc} & \text { Ohne Säure } & \text { Mit Säure } \\ \text { mit physiologischer Kochsalzlösung . . } & 1: 1200 & 1: 2000 \\ \text { in dreifacher Konzentration }(2 \cdot 55 \text { Proz.) } & 1: 2000 & 1: 4000 \\ \text { in ó prozentigem Schwefelammonium. . . } & 1: 500 & 1: 1000\end{array}$


Durch 1 stündige Inaktivation des Serums bei $60^{\circ}$ wurde nur eine Vergrößerung des Präzipitates bei stärkeren Konzentrationen erhalten, d.h. eine Beseitigung der sogenannten „Hemmungszone“, ohne Anstieg des Gesamttiters: die Erwärmung von Bakteriensuspensionen dagegen führt einen Anstieg des Titers herbei (s. Tabelle $\mathrm{X}$ ).

\section{Tabelle V (pro $1 \mathrm{ccm})$.}

Jede Probe wurde in 9 Probiergläsern à $1 \mathrm{ccm}$ Suspension mit abnehmender Serummenge und 2 Kontrollen ausgeführt.

Cholerakultur Nr. 26 mit spezifischem Serum:

Titer ",pa" $=1: 2000$ (Suspension in physiol. NaCl)

" , = $1: 2000$ (in $2 \cdot 25$ Prozent $\mathrm{NaCl}$ )

$" \quad "=1: 5000$ (in 2.25 Prozent $\mathrm{NaCl}+1$ Tropfen $\mathrm{CH}_{3} \cdot \mathrm{COOH}$ )

[in 10 prozentigem $\left(\mathrm{NH}_{4}\right)_{2} \mathrm{SO}_{4}$ ].

Cholerakultur Nr. 18 mit spezifischem Serum:

Titer , $\mathrm{pa}^{\prime \prime}=1: 100$ (suspendiert in physiol. $\mathrm{NaCl}$ )

$" \quad,=1: 5000$ (suspendiert in physiol. $\mathrm{NaCl}+1$ Tropfen 10 prozentige $\mathrm{CH}_{3} \cdot \mathrm{COOH}$ )

$" \quad, \quad=1: 500$ (suspendiert in 5 Prozent $\mathrm{Na}_{2} \mathrm{SO}_{4}$ ).

Kultur von Typhus abdominalis mit spezifischem Serum:

Titer ,pa" $=1: 2000$ (Susp. in physiol. NaCl)

$" \quad==1: 5000$ (Susp. in physiol. $\mathrm{NaCl}+1$ Tropfen $\mathrm{CH}_{3} . \mathrm{COOH}$ )

", $,=1: 20000$ (Susp. in 5 Prozent $\mathrm{Na}_{2} \mathrm{SO}_{4}$ ).

(Die Suspension von Vibrio cholerae zeigt in 5 Prozent $\mathrm{Na}_{2} \mathrm{SO}_{4}$ eine Erniedrigung, B. Typhi dagegen einen Anstieg des Titers.)

Kultur von Cholera asiat.:

Titer , $\mathrm{pa}^{\mathrm{c}}=1: 1000$ (bei Suspensionen von $1 \cdot 70$ bis $3 \cdot 40$ Prozent $\mathrm{NaCl}$ )

$" \quad$ " = 1:2000 (Suspension von $1 \cdot 70 \mathrm{NaCl}+1$ Tropfen 10 proz. $\left.\mathrm{CH}_{3} . \mathrm{COOH}\right)$

$" \quad,=1: 500$ (Suspension $>3 \cdot 40$ bis $5 \cdot 10$ Prozent NaCl)

$" \quad "=1: 200$ (Suspension von 5.10 Prozent $\mathrm{NaCl}+1$ Tropfen $\mathrm{CH}_{3} . \mathrm{COOH}$ ).

Kultur von Vibrio Cholera asiat. Nr. 19:

Titer ,pa " $=1: 1000$ (Suspension 1.70 und 2.55 Prozent $\mathrm{NaCl}$ )

$, \quad "=1: 2000$ (Suspension 1.70 und 2.55 Proz. $\mathrm{NaCl}+1$ Tropfen $\left.\mathrm{CH}_{3} . \mathrm{COOH}\right)$

$" \quad,=1: 200$ (Suspension $>3 \cdot 40$ bis $5 \cdot 10$ Prozent $\mathrm{NaCl}$ )

$" \quad "=1: 200$ (das gleiche mit'Zusatz von 10 Proz. $\mathrm{CH}_{3} . \mathrm{COOH}$ )

" " $\quad 0$ (das gleiche mit Überschuß von Bssigsäure).

Vibrio berolinensis mit spezifischem Choleraserum:

Titer, ,pa" $=1: 50 \pm$ (Suspension von physiol. $\mathrm{NaCl}$ )

$" \quad "=1: 50 \pm$ (das gleiche mit Emuls. bis 3.40 Prozent $\mathrm{NaCl}$ )

$" \quad$ " $\quad$ "Suspension $>4.25$ Prozent $\mathrm{NaCl}$ )

$" \quad " \quad 0$ (sämtliche Konzentrationen von $\mathrm{NaCl}+$ Essigsäure). 
Größerer Zusatz von Essigsäure, 3 bis 4 Tropfen der gleichen 10 proz. Lösung, erzeugte Pseudopräzipitate sogar bei Verdünnung 1 zu 1000 in der Suspension von V. berolinensis. Gleiche Resultate sind bei V. non phosphorescens beobachtet worden.

Typhussuspension: $1 \mathrm{ccm}+$ Serum der Kranken (9. Krankheitstag): Titer , $\mathrm{pa}^{6 "}=1: 200$ (diese und die folgenden in physiologischer Kochsalzlösung).

Typhussuspension: $1 \mathrm{cem}+$ Serum des Kranken (9. Krankheitstag): Titer , $\mathrm{pa}^{\text {" }}=1: 1000$ (nach 25 Stunden wurde den vorigen 1 prozentiges Krankenserum hinzugefïgt).

Typhussuspension + Serum eines schwach immunisierten Kaninchens: Titer ,pa" $=1: 200$ (nach 24 Stunden wurde zu den positiven und negativen Probiergläsern 1 prozentige Menge des gleichen Serums hinzugefügt).

Typhussuspension + Serum eines schwach immunisierten Kaninchens: Titer ,pa ${ }^{6}=1: 2000$.

Aus den recht zahlreichen Versuchen, deren Teil in den der vorliegenden Arbeit beigefuigten Tabellen zusammengefaßt ist, geht klar hervor, daß von sämtlichen, die Suspension beeinflussenden Substanzen Essigsäure in geringen Mengen den Präzipitationstiter, bei nicht allzu großem Salzgehalt, zu erhöhen vermag.

Die Theorie der Kolloidchemie liefert uns eine Begründung für diese Tatsache. Globuline lösen sich in verdünnten Neutralsalzlösungen auf, sind aber ganz unlöslich in reinem Wasser. Ein Überschuß von Salz fällt die Globuline, die sich bei Verdünnung wiederum auflösen. ${ }^{1}$ Nach Hardy ${ }^{2}$ stellt das Globulin einen im Wasser unlöslichen Körper vor, dessen Lösbarkeit in Alkalisalzen als Bildung von Doppeltverbindungen aufzufassen ist. Gleich wie bei anorganischen Verbindungen, bildet das Globulin mit Chlornatrium die Verbindung $\mathrm{Na} \cdot(\mathrm{Glob}.) \mathrm{Cl}$; diese Verbindung dissoziiert sich nach folgender Formel:

$$
\mathrm{Cl} \cdot(\text { Glob. }) \cdot \mathrm{Na} \gtrless \mathrm{Cl} \cdot(\text { Glob. })^{1}+\mathrm{Na} .
$$

Bei Gegenwart von Chlornatrium wird der Abbau gewissermaßen unterdrückt. Bei hochgradiger Verdünnung spaltet sich die obige Verbindung, indem sie unlösliches Globulin nach folgender Formel bildet:

$$
\mathrm{Cl} \cdot\left(\text { Glob.) } \cdot \mathrm{Na}=\mathrm{Na}+\mathrm{Cl}^{1}+\right.\text { (unlösl, Glob.), }
$$

wobei die Trübung beträchtlicher wird. Bei mittlerer Sättigung der Kochsalzlösung bleibt der größere Teil des Globulins in der Lösung zurïck in

1 Richard Zsigmondy, Kolloidchemie. Leipzig 1912. Kapitel Eiweißkörper. S. 246.

${ }^{2}$ Hardy, Journ. of Physiol. 1905. Bd. XXXIII. S. 251-337. 
Gestalt von Elektrolyten, der kleinere Teil dagegen nimmt die Form von Submikronen an. In den stärker konzentrierten NaCl-Lösungen wird die Spaltung der Verbindungen von Globulin mit Chlornatrium unterdrückt, und es erfolgt eine Sedimentbildung.

Mit den vorgeführten Ansichten stimmen die Beobachtungen von Michaelis ${ }^{1}$ überein, welcher festgestellt hat, daß die mit Wasser verdünnten Globulinlösungen weit mehr Ultramikronen enthalten, als die mit physiologischer Kochsalzlösung verdünnten Lösungen. Die Kolloidlösungen sind weniger reversibel und fällen keine Globulinteilchen, was am bequemsten auf die elektrische Ladung der Globulin-Ultramikronen zurückgeführt werden kann. Diese schematischen Befunde konnten nach folgender Formel ausgedrückt werden:

$$
\text { (C) }+\mathrm{Cl} \cdot \mathrm{Glob}^{1}=(\mathrm{C}) \cdot \mathrm{Cl} \cdot \mathrm{Glob}^{1}
$$

Was die Verbindung von Globulinen mit Säuren und Alkalien betrifft, so setzt Hardy die Entstehung von eigentlichen Eiweißionen voraus, denen die Hydrolyse entgegenwirkt. Verbindungen von Globulin mit schwächeren Säuren erleiden Hydrolyse und bilden dabei Ultramikronen in weit größerer. Menge als Verbindungen mit stärkeren Säuren. Wie erwähnt, sind die aus Verbindungen von Salz mit Globulin entstandenen Ultramikronen elektrisch geladen. Geladene Mikronen zeigen ein weit größeres Beweglichkeitsvermögen als eigentliche Eiweißionen; auf Grund dessen unterscheidet Hardy die eigentlichen Ionen von den scheinbaren, $d$. $h$. von geladenen Ultramikronen.

Die Abhängigkeit der Präzipitate vom größeren oder geringeren Zusatz von Essigsäure lüßt sich auf die Elektrolyteneigenbehaften zurückführen. Wie bekannt, wird Serumeiweiß durch stärkeren Zusatz von Alkalien- und Magnesiumsalzen gefällt; Eiweißfällung wird durch Anionen bewirkt. Nahmen wir z. B. die Natriumsalze verschiedener Säuren, so ist das Fällungsvermögen von der Säure allein abhängig und zwar in folgender Reihe: Am stärksten wirken: Citrat $>$ Tartrat $>$ Sulfat $>$ Acetat $>$ Chlorid $>$ Nitrat $>$ Jodid $>$ Rhodanid: Acetat fällt stärker als Chlorid. Wenn wir also in ein ausschließlich Chlorionen enthaltendes Milieu Essigsäureionen einführen, so steigern wir dadurch das Präzipitationsvermögen. Diese Befunde erklären uns, weshalb Essigsäure nur bei gewissen Konzentrationen von $\mathrm{NaCl}$ das Präzipitat zu vergrößern vermag; dagegen bei übermäßiger Sättigung (vgl. Tab. III) wird der Einfluß von $\mathrm{CH}_{3} . \mathrm{COOH}$ durch den Überschuß von Chlorionen unterdrückt.

1 Virchows Arch. f. path. Anat. u. Phys. 1905. Bd. CLXXIX. S. 195-208. 
In der Literatur gibt es recht zahlreiche Befunde uiber den Einflub von Säuren, besonders von Essigsäure, auf den Agglutinationsverlauf, ${ }^{1}$ Es wurde beobachtet, daß Choleravibrionen bei Gegenwart von 1 prozentiger Kalilauge ihre Agglutinogenbeschaffenheit im Verhalten gegen spezifisches Serum verlieren (Neufeld). Neisser und Friedemann haben das Vermögen wahrgenommen, durch den geringsten Zusatz von Säure Typhusbazillen zu fällen. Bei jeder Reaktion erfolgen die Präzipitate immer rascher (Kraus), die saure Reaktion begünstigt die Sedimentbildung, insofern die letztere durch organische Säuren - durch Essigsäure oder saure Salze - (phosphorsaures Natrium) herbeigeführt wird (Rostoski). Eine Abnahme des Fällungsvermögens bei Typhusbazillen wurde beobachtet: von Wassermann - bei Anwendung von stark alkalischen Nährböden; von Lentz und Tietz - die sich des Malachitgrüns bedienten, von Kirstein in Kulturen von Typhusbazillen in eiweißlosem, mit Harn vermengtem Agar. Der letzgenannte Verfasser beobachtete einen Anstieg des Titers in Kulturen von Typhusbazillen auf Kartoffeln mit Zusatz von 1 prozentiger Essigsäure. In sämtlichen dieser Fälle kehrte der Titer - sowohl nach Abnahme, als auch nach Anstieg - zu seiner früheren Norm zurück, sobald gewöhnliche Nährböden angewendet wurden. Eisenberg ${ }^{2}$ führte durch Vermengung eines Teiles von Serum mit einem gleichen Teil von $\mathrm{HCl} \cdot 1 / 2 \mathrm{~N}$ eine Inaktivation herbei; desgleichen auch durch $\mathrm{Zu}$ satz von $\mathrm{H}_{2} \mathrm{SO}_{4}$, was teilweise aktiviert werden konnte durch rasches Neutralisieren der Säure. Aus den Arbeiten von Winterberg ist es gleichfalls bekannt, daß ein Überschuß von Essigsäure auf Agglutinine beeinträchtigend einwirkt.

Die meisten Forseher haben eine Analogie zwischen der Bakterienagglutination und den durch Elektrolyten bisweilen auch durch Nichtelektrolyten bedingten Sedimenten der Kolloidsuspensionen anerkannt: ein Unterschied wurde nur im Einfluß der Alkali- und Erdalkalisalze beobachtet. In den letzten Jahren befaßte man sich nicht wenig mit der sogenannten Säureagglutination der Bakterien, besonders der Typhusbazillen. Nach Michaelis soll das Koagulationsoptimum von denaturiertem Eiweiß mit dem isoelektrisehen Punkte zusammenfallen, welcher bei schwachsaurer Reaktion von Eiweißlösungen entsteht. Was Bakterien anbelangt, so werden dieselben nur bei einem bestimmten Säuregrad gefällt, der aber für diverse Bakterienarten ungleich ist; infolgedessen soll nach Michaelis

1 Näheres siehe bei Paltauf und Kraus im II., und bei Fornet im III. Band d. Handb. v. Kolle-Wassermann, 2. Aufl.

${ }^{2}$ Centralbl. t. Bakteriol. 1906. Bd. XLI. S. $760 \mathrm{ff}$.

${ }^{3}$ Deutsche med. Wochenschr. 1911. \$. 969 u. Centralbl. f. Bakteriol. 
die Säureagglutination bei Differenzierung der Bakterienarten angewendet werden. Nach Beniasch ${ }^{\mathbf{1}}$ ist die Säureagglutination weder auf Säuren, noch auf Anionen, sondern allein auf H-Ionen zurückzuführen, und erfolgt dieselbe nur bei einer bestimmten Konzentration von. H-Ionen $(H)$ : für Typhusbazillen beträgt deren Optima $=4 \times 10^{-5}$. Die Gruppe Bac. enterid. befindet sich im Bereiche der gleichen Konzentration: Paratyphus A und B liegen in den gleichen Konzentrationsgrenzen der H-Ionen; auch lassen sich auf diesem Wege der Bac. diphtheriae vom Bac. pseudodiphtheriae und überhaupt die spezifischen Bakterien von den analogen nicht unterscheiden. Die Säureagglutination wird durch Salze unterdrückt.

In meinem Bestreben, einen möghichst hohen präzipitativ-agglutinativen Titer $\mathrm{zu}$ erlangen (",pa"), habe ich weiter noch folgende Untersuchungen über den Einfluß von sauren und alkalischen Nährböden auf die Bakterieneigenschaften ausgeführt. $\mathrm{Zu}$ diesem Zweck bediente ich mich der genau nach der Madsenschen Skala titrierten Nährböden, und zwar der sehwachsauren $\left(+20^{\circ}\right)$, der schwachalkalischen $\left(-20^{\circ}\right)$, der alkalischen $\left(-60^{\circ}\right.$, und $\left.-105^{\circ}\right)$. Auf solchen Agarnährböden wurden B. typhi abdomin. und V. cholerae asiat. (Kultur Nr. 36) geimpit. Die Kultur dauerte 20 Stunden bei $37^{\circ} \mathrm{C}$; nach vorangegangener Aussäung auf neutralen Nährböden $0^{\circ}$ Madsen, wurden daraus Suspensionen hergestellt, dieselben zur Kontrolle auf 3 Stunden in den Brutofen gestellt und zuletzt mit hochagglutinierendem Choleraserum und Typhusserum agglutiniert in Verdünnung $1 . \mathrm{zu} 50$ bis $1 \mathrm{zu} 20000$, d. h. weit über den Titer dieser Sera hinaus (vgl. Tab. VI).

Da es sich zeigte, daß ein Anstieg des Titers bis 1:20000 nur bei Anwendung von Bakteriensuspensionen aus sauren Nährböden erfolgte $(+20 \mathrm{M}$.), so wurde nachträglich aus einer 2 tägigen Kultur eine Suspension dargestellt, um den höchsten Titer zu bestimmen. Es zeigte sich sodann, daß ,pa" ausgesprochen positiv ist:

für Typhussuspension bei Serumverdünnung bis 1:200000!

für Cholerasuspension erhob sich ,,pa“" nicht über 1:20000.

Sowohl die Erniedrigung des Titers bei Alkalinährböden, wie auch der Anstieg desselben waren ebenfalls mehr ausgesprochen für Typhusbazillen.

Aus den auf neutralen Nährböden geimpften Kulturen $\left(0^{\circ} \mathrm{M}\right.$.) wurden nach 2 Stunden Emulsionen bereitet, um die Reversibilität des Phänomens zu bestimmen, d.h. zu ermitteln, ob die Erniedrigung und der Anstieg reversibel oder irreversibel sind. Die Einzelheiten und Resultate dieser Untersuchungsreihe sind in Tab. VI zusammengestellt.

${ }^{1}$ Zeitschr. f. Immunitätsforsch. 1912. Bd. XII. S. 368 . 
Wie bei den vorhergehenden, so hat sich auch bei diesen Untersuchungen gezeigt, daß die Sensibilisierung der Bakterien vermittelst Essigsäure Typhusbazillen stärker beeinfluBt, als die Choleravibrionen, was Präzipitate und Anstieg des Präzipitationstiters betrifft.

Forschungen über Substitution -von $\mathrm{NaCl}$ dureh schwefelsaures Ammonium (Tabb. VII und VIII) beweisen, daß Suspensionen auch mit 5 prozentigem $\left(\mathrm{NH}_{4}\right)_{2} \mathrm{SO}_{4}$ dargestellt werden können, daß jedoch eine derartige Substitution weder den Reaktionsverlauf, noch die Titerhöhe beeinflussen würde.

Tabelle VI a.

„pa" von Typhusbazillen. Bakteriensuspension aus 1 tägigen Kulturen auf den nach Madsen titrierten von +20 bis -105 Nährböden. Spezifisches Serum von immunisierten Tieren.

\begin{tabular}{|c|c|c|c|c|c|c|c|c|c|}
\hline \multirow{2}{*}{$\begin{array}{l}\text { Titer } \\
\text { "pa }\end{array}$} & \multicolumn{4}{|c|}{ Skala v. M. } & \multicolumn{4}{|c|}{$\begin{array}{l}\text { Reversibilität d.Phänom. } \\
\text { aus d. Nährböden } 0^{\circ} \text { M. } \\
\text { Passagen }\end{array}$} & \multirow{2}{*}{ (pro $1 \mathrm{ccm})$} \\
\hline & +20 & -20 & -60 & -105 & $\begin{array}{r}88 \\
+4 \\
+ \\
\end{array}$ & $\begin{array}{l}\text { 용 } \\
1 \% \\
1 \\
\end{array}$ & $\begin{array}{l}80 \\
18 \\
5 \\
\end{array}$ & 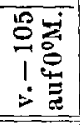 & \\
\hline $1 / 50$ & + & + & + & + & + & + & + & + & In den 4 senkrechten Ru- \\
\hline $1 / 100$ & + & + & + & + & + & + & + & + & briken rechts, ,pa" in den \\
\hline $1 / 200$ & + & + & + & + & + & + & + & + & Typhusbazillensuspensionen \\
\hline $1 / 500$ & + & + & + & + & + & + & + & + & denen das Material v, sauren \\
\hline $1 / 1000$ & + & + & + & - & + & + & + & + & $+20^{\circ}$ und von alkalisehen \\
\hline $1 / 2000$ & + & + & + & - & + & + & + & + & Nährböden bis $-105^{\circ}$ ge- \\
\hline $1 / 5000$ & + & + & + & - & + & + & + & + & impft wurde. \\
\hline $1 / 10000$ & + & + & + & 一 & + & + & + & + & Resultatder Suspensionen \\
\hline $1 / 20000$ & + & + & + & - & + & + & + & + & \\
\hline
\end{tabular}

Kontrollkulturen in 9 Probiergläsern ohne Serum - negativ.

Angesichts dessen, daß der höchste Titer in Suspensionen von schwachsauren Nährböden $+20^{\circ} \mathrm{M}$. (1/20000) betragen hat, ergab eine nachträglich dargestellte ,pa $\mathrm{pa}^{\text {" }}$ aus den gleichen 2 tâgigen Nährböden einen Titer bis an die $1: 200000$ !

\begin{tabular}{c|c}
\hline B. typhi abdomin. & $+20 \mathrm{M}$. \\
\hline $1 / 5000$ & + \\
$1 / 10000$ & + \\
$1 / 20000$ & + \\
$1 / 50000$ & + \\
$1 / 100000$ & + \\
$1 / 200000$ & +
\end{tabular}




\section{Tabelle VI b.}

Cholera „pa" (ebenfalls pro $1 \mathrm{ccm}$ ). Suspensionen der V. cholerae (Kultur Nr. 36) von 1 tägigen Kulturen auf Nährböden, titriert von $20^{\circ}$ bis $-105^{\circ} \mathrm{M}$. Spezifisches Serum immunisierter Tiere. Rechts in der Tabelle - das Phänomen von Reversibilität: von den vorigen Nährböden wurde das Material auf neutrale Nährböden $\left(0^{\circ} \mathrm{M}\right.$.) geimpft und davon Suspensionen dargestellt.

\begin{tabular}{|c|c|c|c|c|c|c|c|c|c|}
\hline \multirow[b]{2}{*}{$\begin{array}{l}\text { Titer } \\
\text { "pa“" }\end{array}$} & \multicolumn{4}{|c|}{ Skala v. Mads. } & \multicolumn{4}{|c|}{ Reversibilität d. Phänom. } & \multirow[b]{2}{*}{ (pro $1 \mathrm{ccm}$ ) } \\
\hline & +20 & -20 & -60 & -105 & $\begin{array}{l}80 \\
+8 \\
+8\end{array}$ & $\begin{array}{l}8: \\
1 \% \\
1:\end{array}$ & $\begin{array}{l}88 \\
18 \\
18\end{array}$ & $\begin{array}{l}80 \\
0 \\
1 \\
1 \\
5\end{array}$ & \\
\hline $1 / 50$ & + & + & + & + & + & + & + & + & \\
\hline $1 / 100$ & + & + & + & + & + & + & + & + & \\
\hline $1 / 200$ & + & + & + & + & + & + & + & + & \\
\hline $1 / 500$ & + & + & + & + & + & + & + & + & \\
\hline $1 / 1000$ & + & + & + & + & + & + & + & \pm & \\
\hline $1 / 2000$ & + & + & + & + & + & + & \pm & - & \\
\hline $1 / 10000$ & + & + &. & - & \pm & \pm & - & - & \\
\hline $1 / 20000$ & + & \pm & - & - & - & - & - & - & \\
\hline $1 / 50000$ & - & - & - & - & - & - & - & - & \\
\hline$-1 / 100000$ & - & - & - & - & - & 一 & 一 & - & \\
\hline
\end{tabular}

Wir sehen also, daß der Anstieg des Choleratiters von sauren Nährböden zwar beträchtlich, jedoch weniger auffallend, als bei Typhussuspensionen ist; das gleiche bezieht sich auf das Reversibilitätsphänomen.

Eine ganze Reihe von Meiostagminbezeichnungen ist ausgeführt worden, um Unterschiede in Oberflächenspannungen der Präzipitinogene zu ermitteln, im. Verhältnis zu denjenigen der Gemische, nach vorangegangener Verbindung der Präzipitinogene mit dem Präzipitin, wobei die Zeit derart berechnet wurde, daß die Reaktion jede zwei Stunden erfolgte, und zwar zwischen der ersten („Période d'impression“" von Bordet) und der zweiten Präzipitationsperiode (,Agglutination proprement dite" - eigentliche Agglutination).

Für einige dieser Versuche wurden Antigene nach der Methode von Ascoli dargestellt. Die Unterschiede zwischen zwei Bezeichnungen sind so gering und unbeständig, ja des öfteren geradezu ganz widersprechend gefunden worden, daß sich aus denselben keine weitergehenden Schlußfolgerungen ziehen lassen, um die Meinung von Pauli zu unterstützen, laut welcher sowohl bei Kolloidpräzipitation, als auch bei Bakterienagglutination die Phänomene auf die Änderungen der Oberflächenspannung 
zurückzuführen sind. Es sei hier angedeutet, daß die meisten eine Erläuterung des Präzipitationsphänomens anstrebenden Theorien berücksichtigten: die Abhängigkeit der Kolloide von den Salzen, die auf Säuren und Alkalien, wie auch auf Metalle zurückzuführenden Adsorptionserscheinungen, die Änderungen der Oberflächenspannung oder der Viskosität (Pauli); doch zeigen diese Befunde keine genaue Analogie weder zur gegenseitigen Reaktion zweier Eiweißkörper, die gegenseitig spezifisch sind und bei Gegenwart von Salzen Niederschläge geben, noch zum Ausbleiben von Niederschlägen in den Fällen, wo einer dieser Körper dem anderen gegenüber nichtspezifisch gewesen ist. Nach den neueren Forschungen von Pribram weisen die Bakteriensuspensionen eine Emulsionsbeschaffenheit auf, welche unter dem EinfluB von spezifischem agglutinierenden Serum einen den Kolloiden eigenen, suspensoiden Charakter erhält.

Tabelle VII.

Präzipitate ohne spez. Sera.

\begin{tabular}{c||c|c}
\hline $\begin{array}{c}\text { In Schwefelamm. } \\
\text { von Konzentration: }\end{array}$ & B. typhi abdom. & V. cholerae asiat. \\
\hline $76 \% \%$ & + & + \\
38 & + & + \\
19 & \pm & \pm \\
9.5 & - & - \\
4.75 & - & - \\
2.38 & - & - \\
1.19 & - & - \\
0.59 & - &
\end{tabular}

Kultur Nr. 21.

„Pä“: f. Typhusbazillen- und Choleravibrionensuspensionen in Schwefelammonium vom Sättigungsgrade $19 \%$ and $9.5 \%$; hochagglutinierende spez. Sera in Verdünnung $1: 50$ bis $1: 200000$. Jede Probe ausgeführt in 10 Probiergläsern und 2 Kontrollen.

Konzentr. v. $19 \%\left(\mathrm{NH}_{4}\right)_{2} \mathrm{SO}_{4} \quad$ Suspensionen: $1 \mathrm{ccm}$

B. typhi + Typhusserum . . . . . . . ,pq" $=1: 1000$

V. cholerae $21+$ Choleraserum : . . . . . $n=1: 2000$

Kontrollen ohne Niederschlag.

Konzentr. v. $9 \cdot 5 \%\left(\mathrm{NH}_{4}\right)_{2} \mathrm{SO}_{4} \quad$ Suspensionen: $1 \mathrm{ccm}$

B. typhi + Typhusserum . . . . . . . "pa" $=1: 1000$

V. cholerae $21+$ Choleraserum . . . . . . . " " $=1: 2000$

(der gleiche Titer wurde in phys. NaCl-Lösung erhalten). 
Serum eines Typhuskranken (4. Woche) + Suspension in $20 \%$ igem Ammoniumsulfat.

\begin{tabular}{|c|c|c|}
\hline & B. typhi abdom. & B. paratyphi B. \\
\hline $1 / 50$ & + (d. gleiche & ++ \\
\hline $1 / 100$ & $+\quad$ Resultat & ++ \\
\hline $1 / 200$ & i.gewöhnl. & ++ \\
\hline Kontrolle ohne & phys. & \\
\hline Serum & - ( NaCl-Lös. & ++ (ohne Serum!) \\
\hline
\end{tabular}

Ich verzichte darauf, eine ganze Reihe von Theorien anzuführen, welche auseinanderzusetzen bezwecken, daß die Agglutination eine ausgesprochen kolloide Reaktion ist, und die Bildung spezifischer Präzipitate sowohl auf die Oberflächenspannung, wie auch auf Änderungen der Lösungskonzentration zurückzuführen ist (bakterielle Eiweißsuspensionen gehören zu hydrophilen oder lyophilen Kolloiden).

Zuletzt habe ich bei der letzten Untersuchungsreihe beobachten können: daß eine 1 stündige Inaktivation der Suspensionen bei 56 bis $64^{\circ}$ die Titerhöhe der ,pa" begïnstigt, ein Komplementzusatz auf dieselben nur schwach einwirkt, und das Erwärmen des Serums gar keinen Einfluß ïbt. ${ }^{1}$

$$
\text { Tabelle VIII. }
$$

Physikalische Änderungen in serumlosen Bakteriensuspensionen und mit Zusatz von Serum in den Grenzen von ,"pa". V. cholerae asiat. + Choleraserum (Verdünnung 1:1000).

Meiostagmische Reaktion von Ascoli mit Hilfe des Stalagmometers (pro $1 \mathrm{ccm}$ ).

\begin{tabular}{|c|c|c|c|}
\hline $\begin{array}{l}\text { Konzentr. } \\
\text { d. }\left(\mathrm{NH}_{4}\right)_{4} \mathrm{SO}_{4} \\
\text { Lösung }\end{array}$ & $\begin{array}{c}\text { Lösung } \\
\text { v. Sehwefelamm. } \\
+ \text { Bakterien } \\
\text { (ohne Serum) }\end{array}$ & $\begin{array}{l}\text { Bakter-Suspens. } \\
\text { i. Sehwefelamm. } \\
+ \text { Serum } \\
\text { (2 St. im Thermo- } \\
\text { stat) }\end{array}$ & $\begin{array}{l}\text { Anstieg } \\
\text { (im Stalag- } \\
\text { mometer) }\end{array}$ \\
\hline $5 \%$ & 17.0 & $18 \cdot 2$ & 1.2 \\
\hline 10 & $17 \cdot 1$ & $18 \cdot 3$ & $1 \cdot 2$ \\
\hline 15 & $17 \cdot 5$ & $18 \cdot 2$ & 0.7 \\
\hline 20 & 18.5 & $19 \cdot 1$ & 0.6 \\
\hline 25 & $17 \cdot 5$ & $19 \cdot 0$ & $1 \cdot 5$ \\
\hline 30 & $17 \cdot 6$ & $19 \cdot 6$ & $2 \cdot 0$ \\
\hline 35 & $18 \cdot 0$ & $19 \cdot 6$ & $1 \cdot 6$ \\
\hline 40 & $17 \cdot 7$ & $21 \cdot 2$ & $3 \cdot 5$ \\
\hline
\end{tabular}

1 Vergleiche C. Moreschi, Beschleunigung und Verstärkung der Bakterienagglutination durch AntieiweiBsera. Centralbl. f. Bakteriol. 1907. Bd. XLVI. S. 456 . 
Kontrollen ohne Spontansedimente nur in den 5- und 10 prozentigen Lösungen.

Bestimmung des elektrischen Leitungsvermögens der Suspension von Typhusbazillen in $5 \%$ iger $\left(\mathrm{NH}_{4}\right)_{2} \mathrm{SO}_{4}$-Lösung (bei vergleichendem Widerstand $=80$ Ohm):

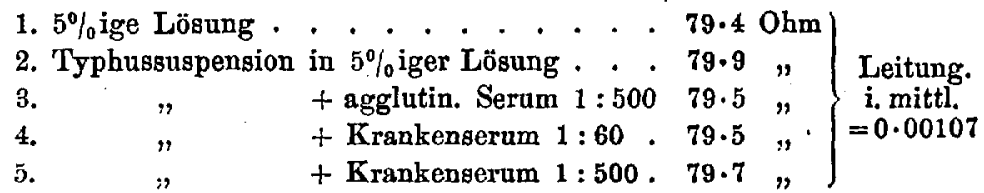

$0.85 \%$ ige $\mathrm{NaCl}-$ Lösung (vergleichender Widerstand von $70 \mathrm{Ohm}$ ):

1. bakterienlose $0.85 \%$ ige Lösung . . . $76.5 \mathrm{Ohm}$

2. Typhussuspensionen . . . . . . . $\mathbf{7 7 . 3} "$ Leitung.

3. $" \quad$ + agglut. Serum 1:500 77.5 " i. mittl.

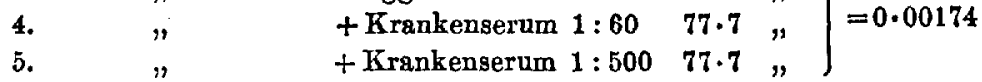

$\mathbf{2 \cdot 5 5} \%$ ige NaCl-Lösung (vergleichender Widerstand $80 \mathrm{Ohm}$ ):

1. Lösung allein $2 \cdot 55 \%$. . . . . . . . $79.4 \mathrm{Ohm}$

2. mit Bakteriensuspension . . . . . $79 \cdot 7$ "

+ agglut. Serum 1:500 79.6" Leitung.

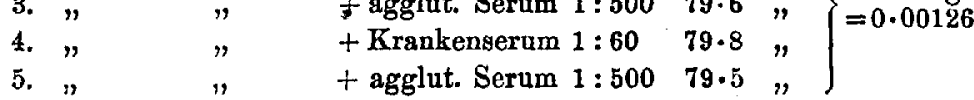

Tabelle IX a. ${ }^{1}$

Meiostagminreaktion von Ascoli. Einfluß der Verbindungen von Agglutininen mit komplementhaltenden oder komplementlosen Agglutinogenen auf die Oberflächenspannung.

Hochagglutinierendes Typhusserum.

\begin{tabular}{|c|c|c|c|c|c|}
\hline $\begin{array}{l}\text { Typhusser., } \\
\text { verd. } 1: 20\end{array}$ & $\begin{array}{c}\text { Typhusser. } \\
\text { + 24 std. } \\
\text { Typhusantig. } \\
\text { (Ascoli) }\end{array}$ & $\begin{array}{c}\text { Typhusser. } \\
\text { + } 24 \text { std. } \\
\text { Typhusantig. } \\
\text { + Komplem. }\end{array}$ & $\begin{array}{c}\text { Erwärmt: } \\
\text { Typhusser. } \\
\text { + } 24 \text { std. } \\
\text { Typhusantig. } \\
\text { + Komplem. }\end{array}$ & $\begin{array}{l}\text { Typhusser. } \\
\text { + Cholera- } \\
\text { antigen }\end{array}$ & $\begin{array}{l}\text { Typhusser. } \\
\text { + Cholera- } \\
\text { antigen } \\
+ \text { Komplem. }\end{array}$ \\
\hline $\begin{array}{l}-0.5 \\
-0.5 \\
-0.2 \\
+0.3\end{array}$ & $\begin{array}{l}+0.6 \\
+0.5 \\
+0.5 \\
-0.5 \\
+0.3\end{array}$ & $\begin{array}{l}+0.9 \\
+0.6 \\
-1.0 \\
+0.8\end{array}$ & $\begin{array}{l}+1.0 \\
-0.2\end{array}$ & $\begin{array}{l}+1.4 \\
+0.5 \\
-0.4\end{array}$ & $\begin{array}{l}+0.6 \\
+0.5 \\
+1.5\end{array}$ \\
\hline
\end{tabular}

1 Frl. K. Sterling ist mir bei der Austuhrung der Meiostagminreaktion behilflich gewesen (Tabb. VII, IXa, IXb). 
Hochagglutinierendes Choleraserum.

\begin{tabular}{|c|c|c|c|c|c|c|c|}
\hline 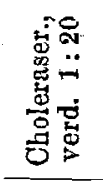 & 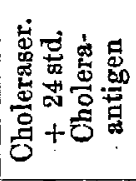 & 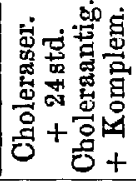 & 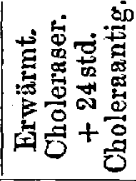 & 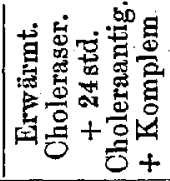 & 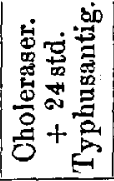 & 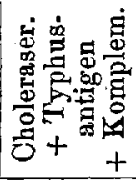 & 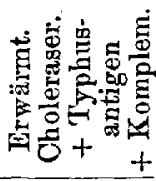 \\
\hline+0 & $\begin{array}{c}+2.1 \\
-0.7 \\
0\end{array}$ & $\begin{array}{l}+1.6 \\
+1.5 \\
+0.4\end{array}$ & $-1,4$ & $\begin{array}{c}+0.4 \\
0\end{array}$ & $\begin{array}{l}+0.3 \\
-1.0 \\
-0.4\end{array}$ & $\begin{array}{c}+0.3 \\
0\end{array}$ & $\begin{array}{c}+0.1 \\
0\end{array}$ \\
\hline
\end{tabular}

Tabelle IXb.

Änderungen der Oberflächenspannung.

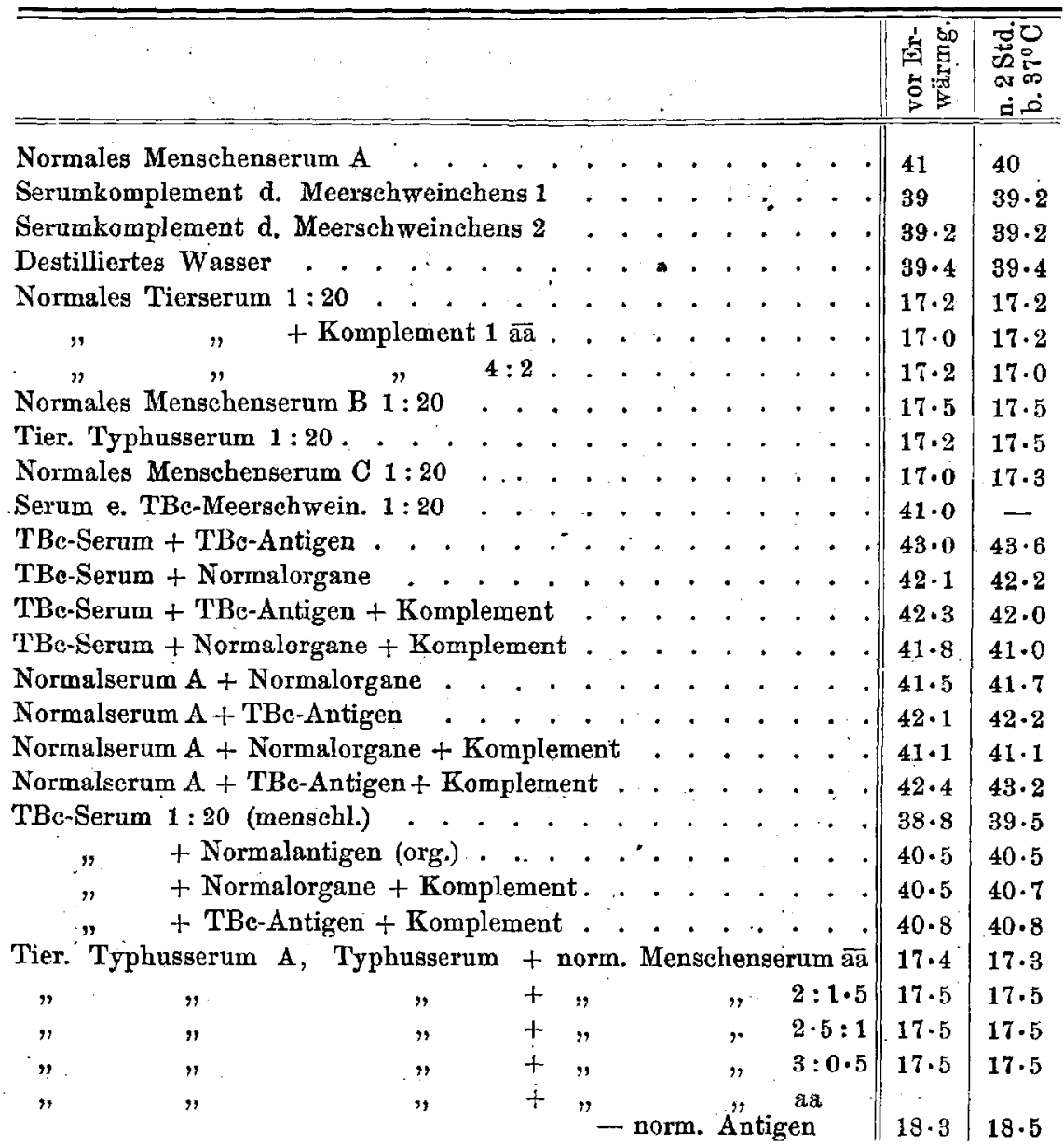


Tabelle IXb (Fortsetzung).

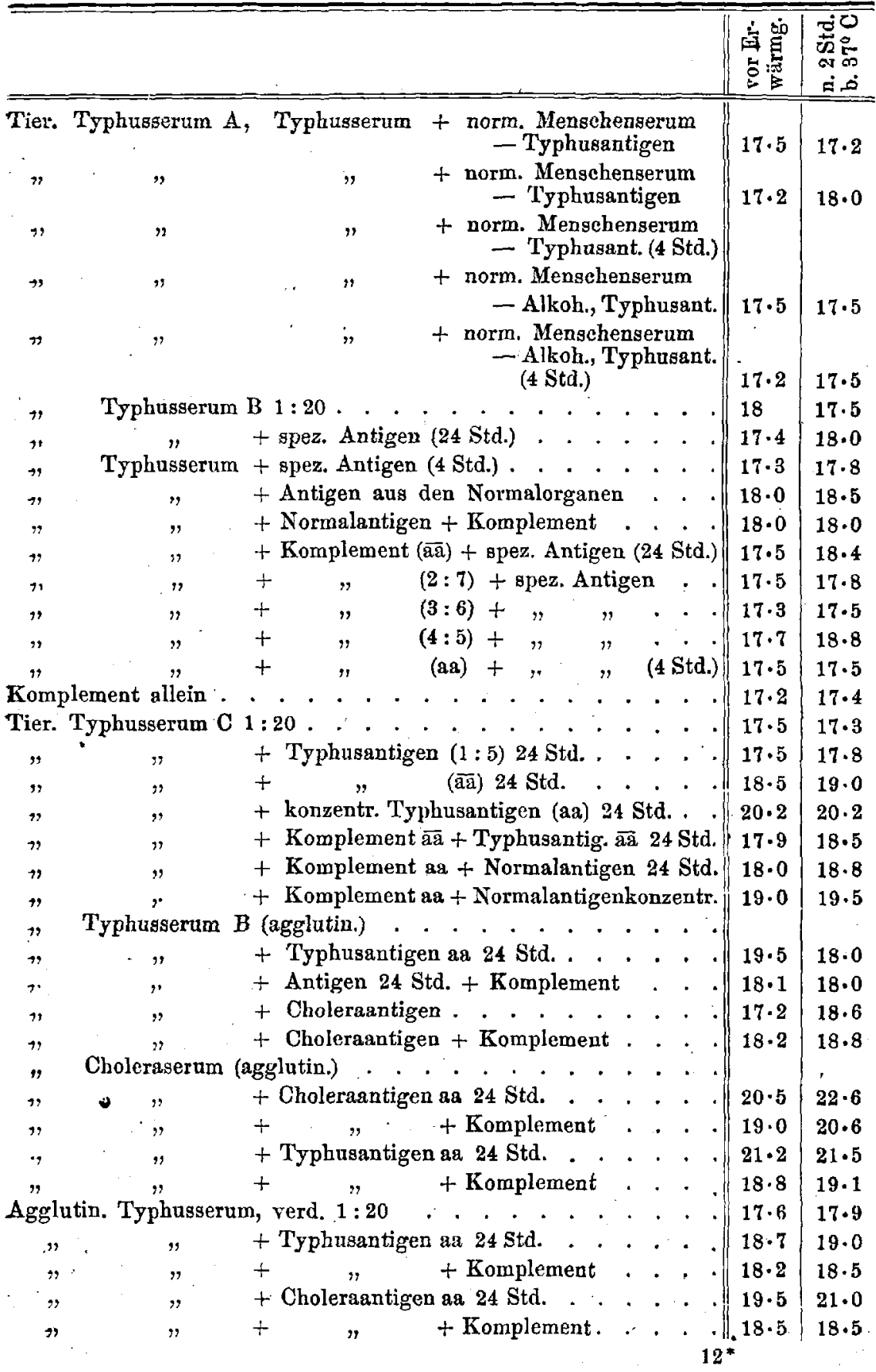


Tabelle X. ${ }^{1}$

Komplementieren der Agglutinine und Präzipitine mit Normalserum (Agglutination pro $1 \mathrm{ccm}$ ).

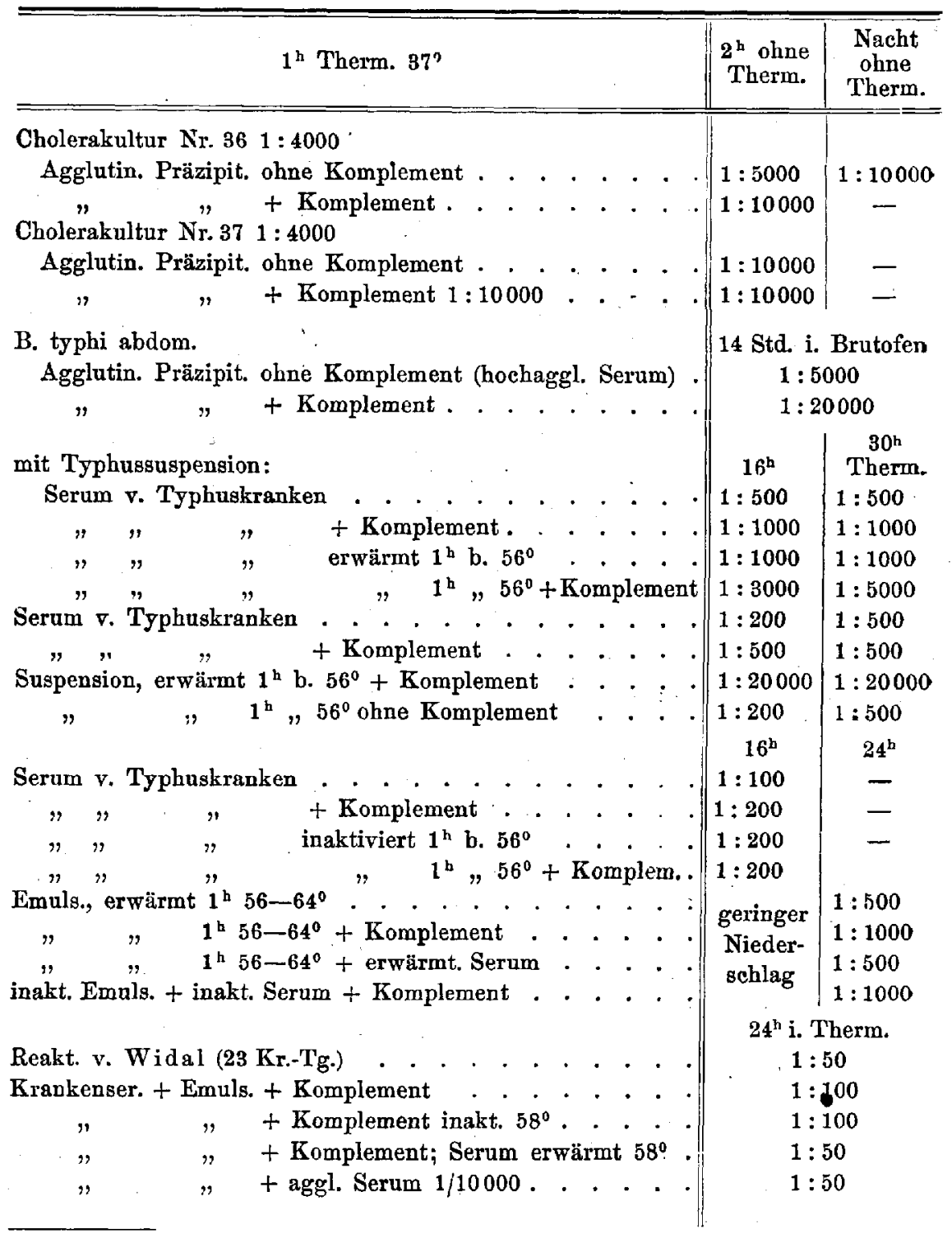

1 Bei Ausführung der in Tabelle $\mathrm{X}$ zusammengestellten Untersuchungen, sowie beim Sammeln des Krankenblutes in den Krankenhäusern leistete mir mein Mitarbeiter, Herr Leon Szereszewski, gefl. Hilfe. 
Tabelle X (Fortsetzung).

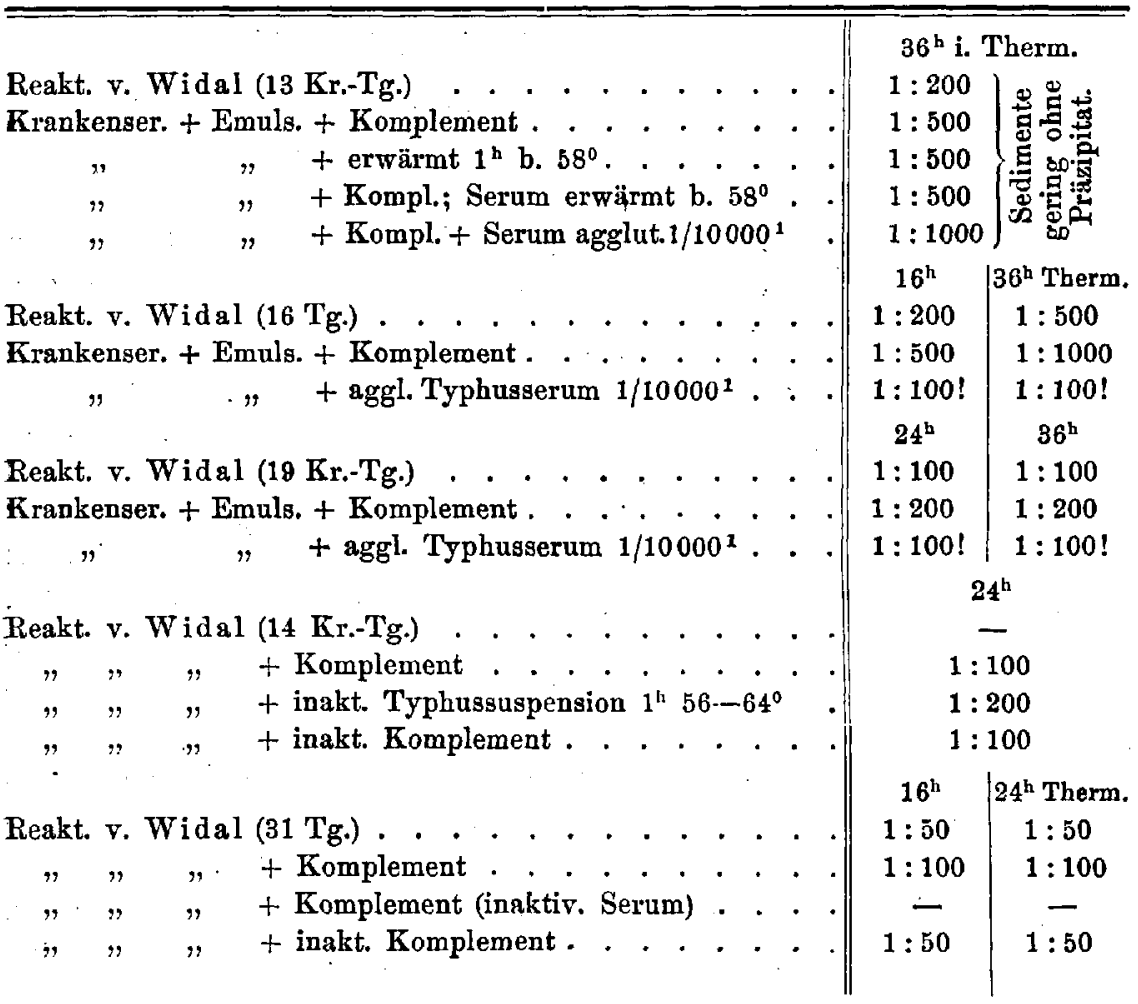

\section{SchluBfolgerungen.}

1. Das Bestreben, einen Anstieg vom Präzipitations- und Agglutinationstiter zu erlangen, bezweckt, eine solche Änderung der Untersuchungsmethode herbeizuführen, welche es ermöglichen würde, spezifische Präzipitine und Agglutinine im Blutserum (frühe Stadien von Typhus, Tuberkulose), in den Krankensekreten und überhaupt bei sämtlichen pathologischen Zuständen zu ermitteln, bei denen negative Resultate der Agglutination und Präzipitation auf einen zu geringen Antikörpergehalt zurückgeführt werden, welcher in quantitativer Beziehung höheren Verdünnungen der spezifischen Sera oberhalb deren Titer entspricht.

2. Ein Anstieg des Agglutinationstiters von .Typhus- und Cholerabazillen ist zu bewirken durch gleichmäßige Vergrößerung von Serum und Sušpensionsmenge von 3 bis 5 bis 10 mal, jedoch in der Weise, daß

${ }^{1}$ Der Zusatz von hochagglut. Typhusserum tiber Titer $\left({ }^{1 / 1} / 0000\right)$ hat den Zweck, die Bakterienemulsion za sensibilisieren: die Ergebnisse waren negativ. 
der Verdünnungsgrad des' Serums und das gegenseitige Verhältnis sämtlicher Bestandteile dabei ungeändert bleibt. Wenn z. B. die Widalsche Reaktion negativ ist, so kann das Serum in beliebiger Weise verdünnt werden, und zwar im Verhältnis von 1: 100, oder 1: 1000 und auch darüber, und von einer jeden dieser Verdünnungen sodánn eine Agglutination pro 3 bis 5 oder mehr (bis $10 \mathrm{ccm}$ ) ausgeführt werden.

3. Bei Titerermittelung ist die Menge der gebrauchten Substanzen $\mathrm{zu}$ berücksichtigen, oder anders gesagt, muß dabei nicht allein der Verdünnungsgrad des Serums, sondern auch das Gemischvolumen angegeben werden $(1,3,5 \mathrm{ccm}$ u. dgl.).

4. Bei Bestimmung von Präzipitation und Agglutination in größeren Flüssigkeitsmengen sind die Kontrollproben mit in Rechnung zu ziehen: z. B. in dem einen Probierglas nur die Suspension allein, im zweiten Serum des Kranken, Suspension heterogener Bakterien (s. Tabb. I u. II: Vermengen von Choleraserum mit Typhussuspensionen und vice versa).

5. Ein sehr auffallender Anstieg des ,pa"-Titers kann durch Bakterienkulturen erreicht werden, besonders durch Typhusbazillen auf Nährböden von $-20^{\circ} \mathrm{C}$ und $+20^{\circ}$ Madsen; bei solchen Proben muB der Aziditäts- und Alkalinitätsgrad des Nährbodens ganz genau angegeben werden: Bezeichnungen wie ,sauer", ,alkalisch" u. dgl. sind dabei unzureichend.

6. Ein Titeranstieg kann ebenfalls durch Zusatz von geringen Mengen 5 bis 10 prozentiger Essigsäure erzielt werden, z. B. 1 Tropfen pro $1 \mathrm{ccm}$ Suspension, insofern die NaCl-Konzentration derjenigen der physiologischen Kochsalzlösung (0.85 Prozent) oder einer zwei- und dreifachen entspricht (2.55 Prozent). Der geringste Zusatz dagegen von $\mathrm{CH}_{3} . \mathrm{COOH}$ zu den stärker konzentrierten Salzlösungen unterdrückt das Phänomen von „„pa ${ }^{\text {c }}$ und erniedrigt den Titer.

7. Ein Zusatz stärkerer Konzentrationen von $\mathrm{CH}_{3}$. $\mathrm{COOH}$ muß unterlassen werden, wenn die gegebene Reaktion nicht völlig unterdrückt werden soll. Auch dürfen $\mathrm{zwei}$ verschiedene. Methoden nicht vereinigt werden, um einen möglichst hohen Titer zu erhalten, weil dabei spontane Niederschläge ohne Beteiligung des Serums erfolgen könnten; z. B. eine Typhussuspension von Nährböden $+20^{\circ}$ Madsen darf mit $\mathrm{CH}_{3} \cdot \mathrm{COOH}$ nicht vermengt werden, da sich dabei nicht-spezifische Sedimente bilden.

8. Konzentration der Salze über 1.70 Prozent oder Substitution von $\mathrm{NaCl}$ durch $\left(\mathrm{NH}_{4}\right)_{2} \cdot \mathrm{SO}_{4}$ und durch andere Salze ist als allgemeine Methode nicht zu empfehlen, obschon diese Vorgangsweise wohl einen Anstieg des „pa"-'Titers in bezug auf einzelne Bakterienarten (z. B. einen der Cholerastämme) zeigen mag. 
9. Obgleich die Ringprobe positive Resultate ergibt, darf sie dennoch für'praktische Agglutinationszwecke nicht empfohlen werden, in Erwägung der methodischen Schwierigkeiten; das gleiche bezieht sich auf die Proben mit ausgetrockneten Bakterienpräparaten.

10. Ein Anstieg von ,pa"-Titer kann ebenfalls durch Erwärmen der Bakteriensuspensionen bis $56^{\circ}$ und nicht über $64^{\circ} \mathrm{C}$ herbeigeführt werden; dagegen weder das Erwärmen der Sera, noch das Komplementieren mit frischem Serum vermag in dieser Richtung einen meßbaren Einfluß zu üben, außer daß in den niedrigeren Verdünnungen die Präzipitate vermehrt werden, und die Wirkung der sogenannten Hemmungszone unterdriickt wird.

11. Die bei antitoxischen Sera angewendete Konzentration darf zur Vergrößerung von Agglutininen und Präzipitinen nicht benutzt werden.

12. Unter dem Einfluß des Serums sowohl von kranken, wie von immunisierten Tieren in Verbindung mit entsprechender Bakteriensuspension (nicht allein mit dem Filtrat der letzteren) erfolgen beide Phänomene parallel in einen und denselben Proben - die Agglutination und die Präzipitation, wobei die Präzipitationssedimente 10 bis $20 \mathrm{mal}$ größer sind als die bakteriellen. Da bei der Agglutination der Titer höher als bei der Präzipitation ist, so können wir bakterielle Niederschläge nur in hohen Verdünnungen erhalten.

13. Mit Hilfe der vorgeführten Methoden kann ein Anstieg vom präzipitativ-agglutinativen Titer der verschiedenen Bakterienarten erzielt werden, obwohl nicht in einem für alle gleichen Grade; von den bereits untersuchten läßt sich der agglutinative und präzipitative Titer der Typhusbazillen am beträchtlichsten steigern, weit schwächer dagegen derjenige vom V. cholerae (Bac. coli com. - negativ).

In der vorliegenden Arbeit stellte ich mir vor allem zur Aufgabe die Bearbeitung einer den ,Titeranstieg“ bezweckenden Methode; doch entscheidet sie keineswegs, inwiefern diese Methoden in der ärztlichen Klinik praktische Anwendung finden könnten. 